\title{
Fluid evolution from quartz veins in micaschists from the thermal aureole around the Acari batholith, Northeast Brazil
}

\author{
Evolução dos fluidos em veios de quartzo encaixados nos micaxistos na auréola térmica no
} entorno do batólito de Acari, Nordeste do Brasil

\author{
Laécio Cunha de Souza1 (D), Regina Celia de Oliveira Brasil Delgado² (D, Heitor Neves Maia1 (D) \\ ${ }^{1}$ Universidade Federal do Rio Grande do Norte - UFRN, Departamento de Geologia, Centro de Ciências Exatas e da Terra - \\ CCET, Av. Senador Salgado Filho, 3.000, CEP 59078-970, Natal, RN, BR (laecio@geologia.ufrn.br; heitor@geologia.ufrn.br) \\ ${ }^{2}$ Universidade Federal Rural do Semi-Árido - UFERSA, Departamento de Engenharia e Tecnologia, Mossoró, RN, BR \\ (regina.brasil@ufersa.edu.br)
}

Received on August 1, 2019; accepted on September 3, 2021.

\begin{abstract}
Micaschists that host the Acari batholith (Ediacaran age, 572 to $577 \mathrm{My}$ ) are characterized by a large number of quartz veins. The veins are more abundant in higher-temperature metamorphic zones and, together with lower metamorphic zones, form an aureole centered in the batholith. Most of the fluid inclusions are two-phase $\left(\mathrm{H}_{2} \mathrm{O}-\mathrm{CO}_{2}\right.$ and liquid/vapor), but three-phase varieties (liquid/vapor/salt cubes; liquid/liquid/vapor) occur locally. The analyzed veins come from the biotite + chlorite + muscovite, biotite + garnet, cordierite + andalusite, and cordierite + sillimanite metamorphic zones. $\mathrm{CO}_{2}$ melting temperatures $\left(\mathrm{TmCO}_{2}\right.$ ) vary from -62.6 to $-56.7^{\circ} \mathrm{C}$, suggesting $\mathrm{CH}_{4}$ and/or $\mathrm{N}_{2}$. Eutectic temperatures (Te) in quartz veins show average values of $-30.8^{\circ} \mathrm{C}$ in the biotite + chlorite + muscovite and biotite + garnet zones, and $-38.6^{\circ} \mathrm{C}$ in the cordierite + andalusite and cordierite + sillimanite zones. Ice-melting temperatures $\left(\mathrm{Tm}_{\mathrm{ice}}\right)$ are lower in the higher-temperature metamorphic zones. The mode values are $-3.8,-5.5,-5.6$, and $-7.3^{\circ} \mathrm{C}$, corresponding respectively to the biotite + chlorite + muscovite, biotite + garnet, cordierite + andalusite, and cordierite + sillimanite zones. A fluid characterized by the $\mathrm{H}_{2} \mathrm{O}-\mathrm{Na}-$ $\mathrm{Cl}(\mathrm{KCl})-\mathrm{MgCl}_{2}-\mathrm{FeCl}_{2}-\mathrm{CaCl}_{2}$ system is defined by: $\mathrm{Tm}_{\text {ice }}$ from near -1.9 to $-32^{\circ} \mathrm{C}$, the presence of salt cubes mainly in the cordierite + andalusite and cordierite + sillimanite zones, and recorded eutectic temperatures (Te) from -16.5 to $-59.1^{\circ} \mathrm{C}$. In addition, total homogenization temperatures (Tht) ranging from 117 to $388^{\circ} \mathrm{C}$ were obtained for primary aqueous fluid inclusions. This indicates a long period of fluid circulation under conditions of falling temperatures. Our results are consistent with an increase in the salinity of the aqueous fluid across the thermal aureole toward the granitic batholith.
\end{abstract}

Keywords: Fluid inclusions; Quartz veins; Micaschists; Thermal aureole; Fluid composition; Salinity.

\section{Resumo}

Os micaxistos que circundam o batólito granítico de Acari (idade ediacarana, 572 a $577 \mathrm{Ma}$ ) são caracterizados por elevada quantidade de veios de quartzo. Os veios são mais abundantes nas zonas metamórficas com temperaturas mais altas, que somadas àquelas de temperaturas mais baixas formam a auréola que envolve o batólito. Os veios analisados são provenientes das zonas da biotita + clorita + muscovita, biotita + granada, cordierita + andaluzita e cordierita + sillimanita. Grande parte das inclusões fluidas são bifásicas, porém as variedades trifásicas podem ser localmente observadas. As temperaturas de fusão do $\mathrm{CO}_{2}\left(\mathrm{TfCO}_{2}\right)$ variam de $-62,6$ a $-56,7^{\circ} \mathrm{C}$. As temperaturas eutéticas $(\mathrm{Te})$ mostram valores médios de $-30,8^{\circ} \mathrm{C}$ nas zonas da biotita + clorita + muscovita e biotita + granada e de $-38,6^{\circ} \mathrm{C}$ nas zonas da cordierita + andaluzita e cordierita + sillimanita. As temperaturas de fusão do gelo (Tfgelo) são mais baixas nas zonas metamórficas de mais altas temperaturas. Os valores das modas são de $-3,8,-5,5,-5,6$ e $-7,3^{\circ} \mathrm{C}$, que correspondem respectivamente às zonas de biotita + clorita + muscovita, biotita + granada, cordierita + andaluzita e cordierita + sillimanita. Um fluido caracterizado pelo sistema $\mathrm{H}_{2} \mathrm{O}-$ $-\mathrm{NaCl}(\mathrm{KCl})-\mathrm{MgCl}_{2}-\mathrm{FeCl}_{2}-\mathrm{CaCl}_{2}$ é definido por: Tfgelo que varia de $-1,9$ a $-32^{\circ} \mathrm{C}$; presença de cubos de sal nas zonas da cordierita + andaluzita e cordierita + sillimanita; e Te registradas entre $-16,5$ e $-59,1^{\circ} \mathrm{C}$. Adicionalmente, foram obtidas temperaturas de homogeneização total que variaram entre 117 e $388^{\circ} \mathrm{C}$ para as inclusões fluidas aquosas primárias. Os resultados são consistentes com o aumento da salinidade dos fluidos aquosos ao longo da auréola, na direção do batólito.

Palavras-chave: Inclusões fluidas; Veios de quartzo; Micaxistos; Auréola térmica; Composição dos fluidos; Salinidade. 


\section{INTRODUCTION}

The metapelites of the Serido Formation, at the top of the stratigraphic column of the Seridó Group, have recorded most of the evolutionary history of Seridó Belt metamorphism (Legrand and Martins Sá, 1986; Lima, 1986; Souza, 1996) during the Brasiliano orogeny ( 700 to $500 \mathrm{Ma}$ ). These metapelites commonly contain important marker minerals of metamorphic conditions, such as sillimanite, cordierite, andalusite, staurolite, and garnet. At the Seridó Formation, represented by a large belt of micaschists, we highlight two metamorphic episodes $M_{1}$ and $M_{2}$. The synchronism of the tectono-metamorphic event $\mathrm{F}_{2} / \mathrm{M}_{2}$ and the granitic batholith setting favored increased heat and the possibility of aqueous and carbonic fluid circulation in the micaschists. Along the aureole, especially in the highertemperature zones, it is common for metapelites to develop long hydrothermal bands $\left(\mathrm{M}_{2}\right)$, with widths ranging from centimeters to meters, and remarkable growth of cordierite, andalusite, sillimanite, garnet and locally staurolite porphyroblasts, plus swarms of quartz veins of micro- to decimetric size. In this context, a key foundation for interpreting fluid-rock interaction history is the unmatched ability of metamorphic quartz veins in metapelites. These veins encode and record the fluid chemical composition and geothermobarometric conditions in their fluid inclusions, also attending index mineral growth. Therefore, along these metamorphic bands $\left(\mathrm{M}_{2}\right)$, the interaction of a fluid phase with the mineral phases enhances hydrolysis/ ionic reactions, which enclose dissolution and precipitation (Bucher and Frey, 1994; Miyashiro, 1994; Souza et al., 1996), combined with the solubility of diffusing components in the intergranular medium (Carlson et al., 2015; Souza and Carvalho, 2015). These mechanisms of mineralogical transformation allowed the growth of the index minerals and the formation of the associated quartz veins (Souza, 1996).

Therefore, it is plausible that these quartz veins mark the path/conduit through which fluid flow and mass transfer could occur (Yardley and Bortrell, 1992; Carlson et al., 2015; Souza and Carvalho, 2015), which are the target of this work. In this context, the study of fluid inclusions in the Serido Belt has been focused on gold mineralized quartz veins hosted in micaschists (Luiz Silva, 1995) and tungsten mineralized calc-silicate rocks (Salim, 1993). Therefore, this paper investigates fluid inclusions in quartz veins hosted by low- to highgrade metamorphic schists around the Acari granitic batholith. The study relates the metamorphic aureole of the schists to the lateral variation of the fluid inclusion compositions, particularly salinity, in close association with the mineral reactions that form the metamorphic aureole centered in the Acari pluton.

\section{GEOLOGICAL SETTING}

The study site is located in Northeastern Brazil (Figure 1) and covers a surface area of approximately $250 \mathrm{~km}^{2}$. The micaschists are flysch-type pelitic sediments deposited in the Neoproterozoic Seridó Belt metamorphosed during the Brasiliano orogeny (Caby, 1989; Van Schmus et al., 1995; Van Schmus et al., 2003; Hollanda et al., 2015). The micaschists represent the upper unit of the Seridó Group that, in turn, rests on an Archean to the Paleoproterozoic basement (Dantas, 1997; Dantas et al., 2004). These metapelites are well represented in the Seridó Belt and preserve the record of changes of the metamorphic and tectonic conditions that affected the belt in the Ediacaran (Souza, 1996). The regional deformation is characterized by dextral shear zones formed during a transpressive regime. The shear zones acted as pathways that assisted in the injection of synorogenic stocks and batholiths (Archanjo et al., 1992, 2013; Leterrier et al., 1994). The Acari granitic massif has a calc-alkaline affinity with high-K and was emplaced in this context. The massif is completely surrounded by micaschists, which developed a regional metamorphic aureole. Two metamorphic episodes, $M_{1}$ and $M_{2}$, are distinguished. The first episode $\left(M_{1}\right)$ occurred under greenschist facies conditions and developed a schistosity $\mathrm{S}_{1}$, which was superimposed by a medium/high-T/ Low-P greenschist/amphibolite facies episode $\left(\mathrm{M}_{2}\right)$. The second event was responsible for the metamorphic aureole centered on the Acari massif. The textural analysis of metamorphism $\mathrm{M}_{2}$ minerals allowed us to establish several metamorphic zones:

- [1] biotite + chlorite + muscovite (Figure 2 );

- [2] biotite + garnet (Figure 3);

- [3] biotite + cordierite + andalusite (Figure 4);

- [4] biotite + cordierite + sillimanite (Figure 5).

These assemblages, plus plagioclase, quartz (veins), and a fluid phase from dehydration and devolatilization reactions, evolved continually during the tectono-metamorphic $\mathrm{M}_{2}$ episode (Souza, 1996; Souza et al., 2007). Conspicuous mineralogical alternations occur along the micaschists' aureole. These alternations or bands (biotite + plagioclase + quartz \pm garnet versus biotite + cordierite + andalusite or sillimanite \pm plagioclase \pm garnet + quartz), parallel to schistosity $\mathrm{S}_{2}$, have been enhanced by an important growth of the index metamorphic minerals such as garnet, cordierite, staurolite, andalusite, and sillimanite. The metamorphic event $\mathrm{M}_{2}$ formed under transpression, where the main schistosity $\mathrm{S}_{2}$ usually shows a vertical dip. Fluid inclusions data $\left(\mathrm{H}_{2} \mathrm{O}\right.$-rich fluid phase) from the quartz vein system (parallel to this schistosity $\mathrm{S}_{2}$ ) are related to the mineral transformations 


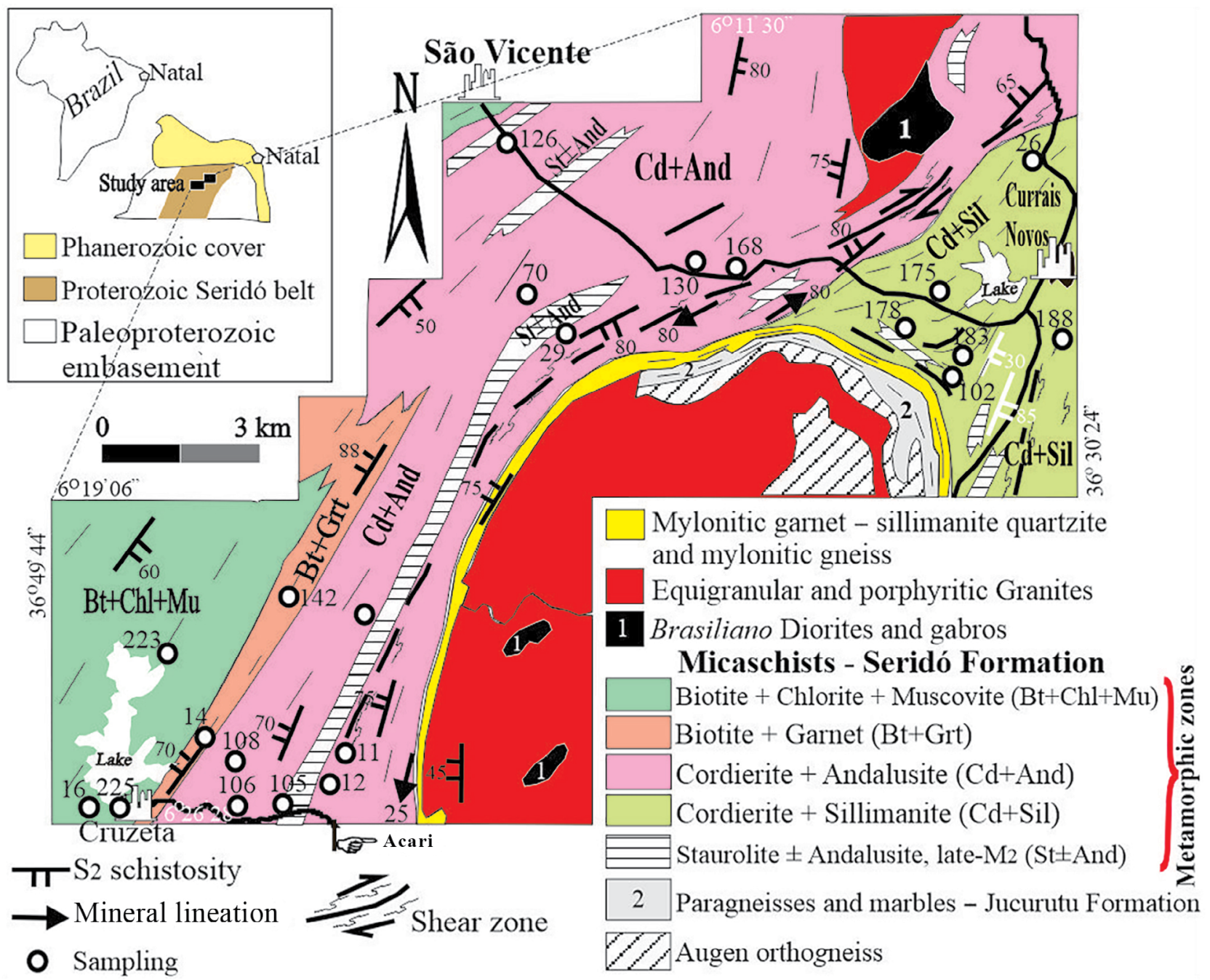

Source: modified from (Souza, 1996).

Figure 1. Neoproterozoic metamorphic aureole in the Acari granitic batholith shows the distribution of metamorphic zones in the Seridó micaschists.

(Souza, 1996). In addition to water-rich fluids, $\mathrm{CO}_{2}$ is also present in variable proportions. The dynamics of $\mathrm{M}_{2}$ metamorphism allowed a continuous recrystallization process to be inferred from early to late metamorphic minerals. The metamorphic reactions started with rising temperatures (progressive metamorphism from M1 in greenschist facies) in the early to the syn- $\mathrm{M}_{2}$ interval. During this interval, the peak temperature reached 600 $-650^{\circ} \mathrm{C}$ at $3-4 \mathrm{kbar}$ in the cordierite + sillimanite zone (Souza, 1996), according to PT estimates from Spear and Peacock (1990). The syn- to late- $\mathrm{M}_{2}$ period was marked by the recrystallization of the index minerals (cordierite, andalusite, sillimanite, staurolite, and garnet) and quartz vein formation, but under a regime of decreasing temperatures.

\section{ANALYTICAL METHOD}

\section{Sample selection of veins}

The samples studied in this work are quartz veins parallel to the $\mathrm{S}_{2}$ foliation in phyllites and micaschists of the Serido host collected in different metamorphic grades of the metamorphic aureole. The location of the veins, their host lithology, and metamorphic grade are summarized in Figure 1. We prepared fifteen wafers of quartz veins and fluid inclusion microthermometry data from the metamorphic zones (Table 1). These quartz veins are usually fine-grained at low metamorphic grades and coarse-grained at high metamorphic grades. In all metamorphic zones, the quartz veins are synchronous with $\mathrm{F}_{2} / \mathrm{M}_{2}$ (Figure 6 ). The sampled veins 

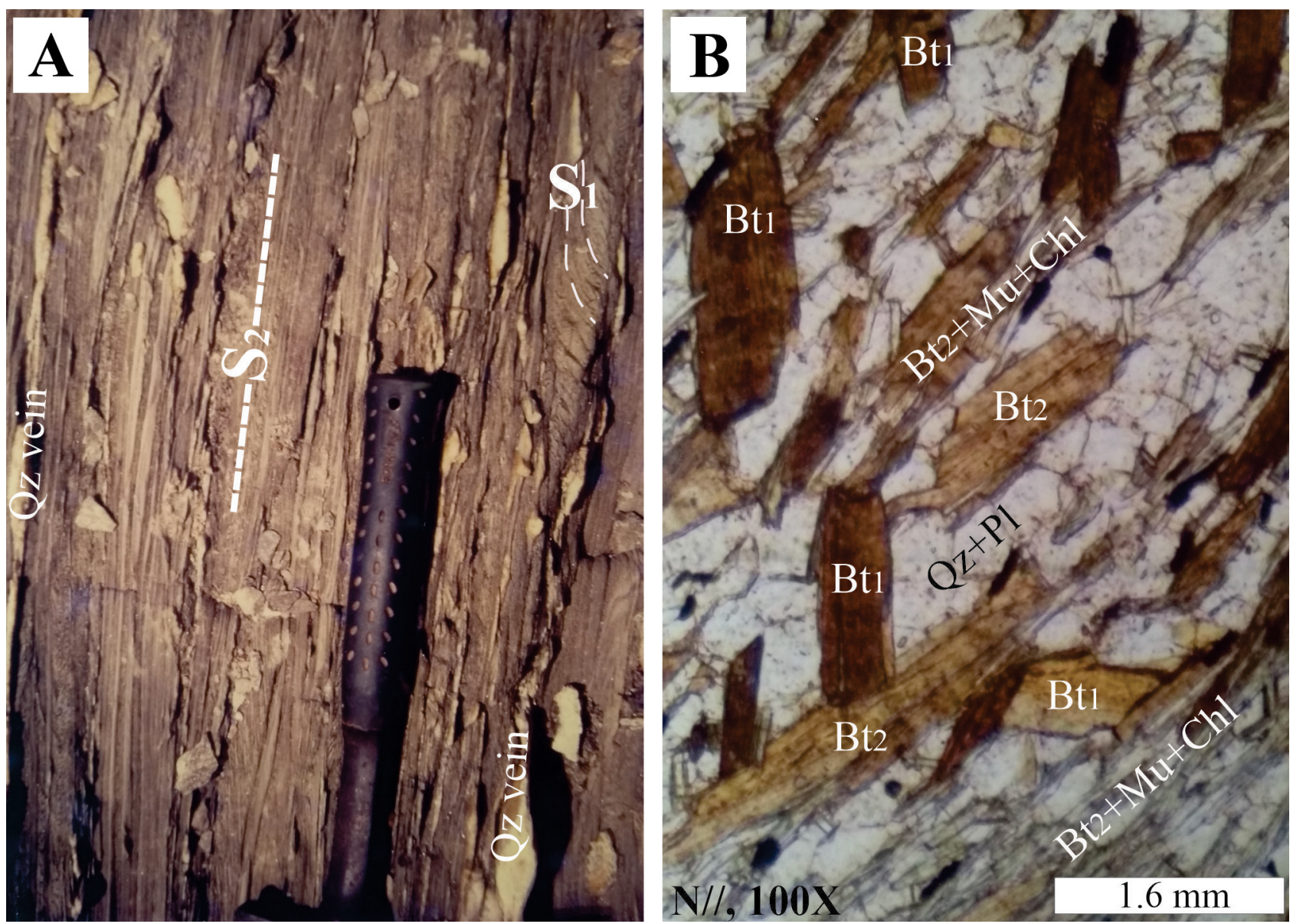

Figure 2. (A) Biotite - chlorite - muscovite phyllite showing a conspicuous foliation $\mathrm{S}_{2}$, overlapping $\mathrm{S}_{1}$, and (B) photomicrography (parallel Nicols, 100X) in the same phyllite with biotite, muscovite and chlorite $\left(\mathrm{Bt}_{2}+\mathrm{Chl}+\mathrm{Mu}\right.$ zone) defining the schistosity $\mathrm{S}_{2}$, in addition to aggregates of plagioclase and quartz $(\mathrm{PI}+\mathrm{Qz})$. This schistosity overlaps the older foliation $\mathrm{S}_{1}$.

are composed of quartz and sometimes include fragments (xenoliths) of the host micaschist. In most cases, the veins are composed exclusively of quartz and late fractures crosscutting the quartz crystals often filled with opaque minerals, Fe-oxide, muscovite, chlorite, and garnet.

\section{Analysis of fluid inclusions}

Fluid inclusions were systematically studied as a function of host quartz generation and its relationship with successive deformation and fracture episodes. The fluid inclusion populations were described and mapped using a petrographic microscope. The petrographic characterization of fluid inclusions was based on the guidelines of Goldstein and Reynolds (1994), considering the sizes, shapes, arrangement of fluid inclusions etc. Microthermometric measurements of fluid inclusions were performed on wafers ( $<250 \mu \mathrm{m}$ in thickness) using an R-Chaixmeca heating-freezing stage (DG-UFRN). This stage was calibrated using natural $\mathrm{CO}_{2}$ inclusions at $-56,6^{\circ} \mathrm{C}$, benzylic alcohol at $-15.3^{\circ} \mathrm{C}$, double-distilled water at $0^{\circ} \mathrm{C}$, and some pure compounds such as benzoic acid at $122.4^{\circ} \mathrm{C}$, Na-nitrate at $306.8^{\circ} \mathrm{C}$, and $\mathrm{K}$-dichromate at $398^{\circ} \mathrm{C}$. The heating rate was monitored to achieve a precision of \pm $0.3^{\circ} \mathrm{C}$ during freezing, $\pm 2^{\circ} \mathrm{C}$ when heating over the $250-$ $350^{\circ} \mathrm{C}$ row, and $\pm 3^{\circ} \mathrm{C}$ over the $350-550^{\circ} \mathrm{C}$ row. The volumetric fractions of the aqueous liquid and the volatile-rich phase were estimated by reference to the volumetric chart of Roedder (1984).

\section{RESULTS}

\section{Fluid inclusion petrography}

To define different fluid inclusions assemblages (FIA's), which are petrographically associated and formed in the same time interval and under similar tectono-thermal conditions, the guidelines of Goldstein and Reynolds (1994) were followed. In this sense, the consistency or not of L:V, similarities in shape, size, and possible orientations of fluid 

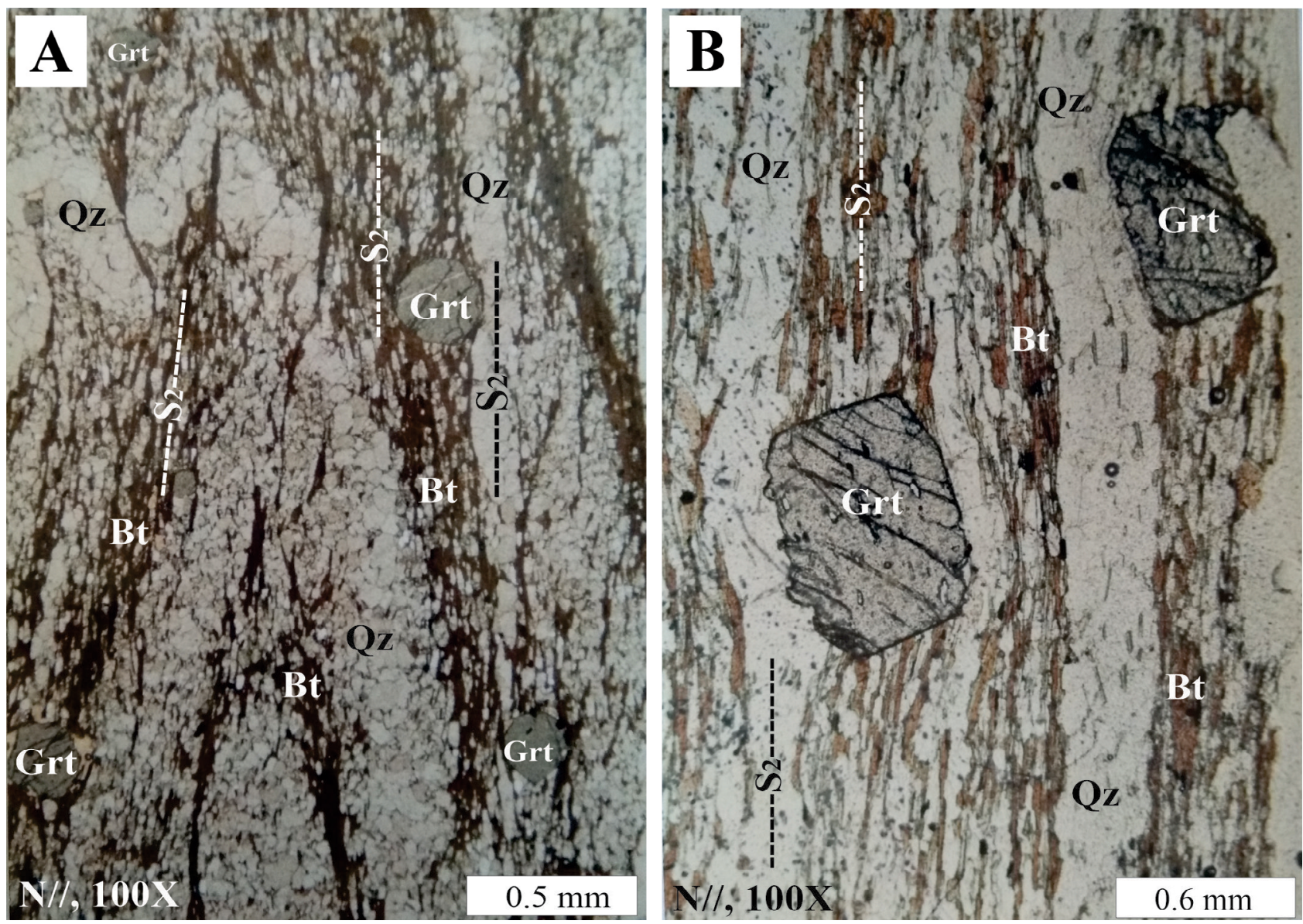

Figure 3. Garnet - biotite schist (biotite + garnet zone) showing growth late-S ${ }_{2}$ of microphenoblasts of garnet (Grt) at the biotite $(\mathrm{Bt})$ aggregate levels, $(\mathrm{A})$ granolepidoporphyroblastic and (B) lepidoporphyroblastic textures, beyond quartz (Qz) veins and penetrating schistosity $\mathrm{S}_{2}$. (both parallel Nicols, 100X).

inclusions were considered. Fluid inclusions in the quartz veins occur in three different settings. The first one forms a cluster with individual isolated inclusions (primary or precocious). The second setting occurs when internal planar trails do not cross the crystal boundaries (pseudo-secondary). In contrast, the third one appears as planar trails that cross the crystal boundary, sometimes in fractures. The latter unequivocally defines secondary inclusions (Figures 7-10). The exact characterization of primary or precocious inclusions associated with metamorphic rocks is sometimes difficult. Nonetheless, clusters and individual fluid inclusions isolated from planar trails can be the oldest inclusions in the sample (Swanenberg, 1980; Crawford and Hollister, 1986). The microthermometric data (Table 1) obtained in this study further support syn-retrograde metamorphism $\left(\mathrm{M}_{2}\right)$ emplacement for these veins and their fluid inclusions. In biotite + muscovite + chlorite and biotite + garnet zones, the size of fluid inclusion is observed to range from c. $5-16 \mu \mathrm{m}$ to c. $5-32 \mu \mathrm{m}$, occasionally reaching up to 16 and $40 \mu \mathrm{m}$, respectively. On the other hand, the size of fluid inclusions in both cordierite + andalusite and cordierite + sillimanite zones ranges from c. $15-40 \mu \mathrm{m}$, with some inclusions reaching up to $76 \mu \mathrm{m}$ (Figure 11).

\section{Fluid inclusion data}

Considering all the metamorphic zones, including the quartz veins in the granitic batholith, a reasonable number of measurements (primary/precocious, pseudo-secondary, secondary) of eutectic ( $\mathrm{Te}$ ) and $\mathrm{CO}_{2}$-melting $\left(\mathrm{TmCO}_{2}\right)$ temperatures was characterized within the ranges of $-59,1$ to $-16,5^{\circ} \mathrm{C}$ and -62.6 to $-56.8^{\circ} \mathrm{C}$, respectively (Table 1 ). These measurements indicate two major types of fluids:

- $\mathrm{a} \mathrm{NaCl}[\mathrm{KCl}(?)]$ - dominated fluid with substantial $\mathrm{CaCl}_{2}$, $\mathrm{MgCl}_{2}$ and $\mathrm{FeCl}_{2}$, mainly in the high-grade metamorphic zones;

- $\mathrm{aCO}_{2}$-rich fluid that was characterized in volatile-bearing inclusions by the melting of a solid below $-56.6^{\circ} \mathrm{C}$, and by $\mathrm{CO}_{2}$ - melted temperatures as low as $-63.3^{\circ} \mathrm{C}$ for fluids displaying $\mathrm{CH}_{4}-\mathrm{N}_{2}$ contents that are likely to be important. 

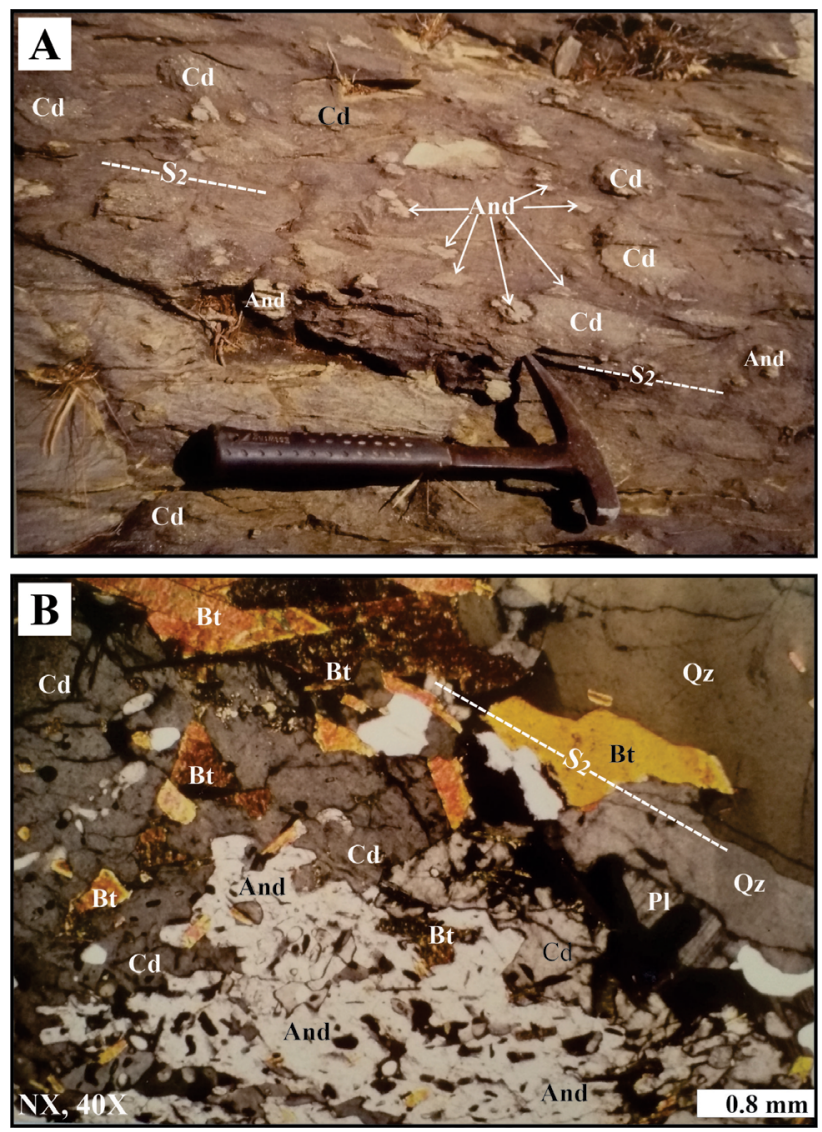

Figure 4. Biotite - cordierite - andalusite schist in the cordierite $(\mathrm{Cd})+$ andalusite (And) zone, with porphyrolepidoblastic texture point out $(A)$ phenoblasts of stretched cordierite, in the $S_{2}$ foliation, and of andalusite (whitish crystals). (B) Photomicrography (crossed Nicols, 40X) shows the growth of poikiloblastic andalusite and cordierite replacing biotite $(\mathrm{Bt})$ and plagioclase $(\mathrm{PI})$.

\section{Fluid inclusions salinity and ice-melting temperature}

The salinity of all fluid inclusions (FI; quartz veins from micaschists) ranges from 20.8 to $3.1 \mathrm{wt} . \% \mathrm{NaCl}$ eq., calculated using the equation of Brown and Lamb (1989), corresponding to the final ice-melting temperatures ranging from -17.8 to $-1.9^{\circ} \mathrm{C}$ (primary and pseudo-secondary FI: $\mathrm{Bt}+\mathrm{Chl}+$ Mu zone; primary FI: $\mathrm{Bt}+\mathrm{Grt}, \mathrm{Cd}+\mathrm{And}, \mathrm{Cd}+$ Sil zones; primary and secondary FI in quartz vein in the batholith) (Figure 12). In aqueous fluid inclusions, salinity within individual metamorphic zones in the micaschists shows a systematical variation. The mode values of $6.1,8.5,8.7$, and 10.9 wt. $\% \mathrm{NaCl}$ eq. correspond, respectively, to the biotite + chlorite + muscovite, biotite + garnet, cordierite + andalusite, and cordierite + sillimanite zones (Figure 13). Saturation salt crystals $[\mathrm{NaCl}, \mathrm{KCl}(?)]$ in aqueous inclusions were found only in the high-grade metamorphic zones (cordierite +
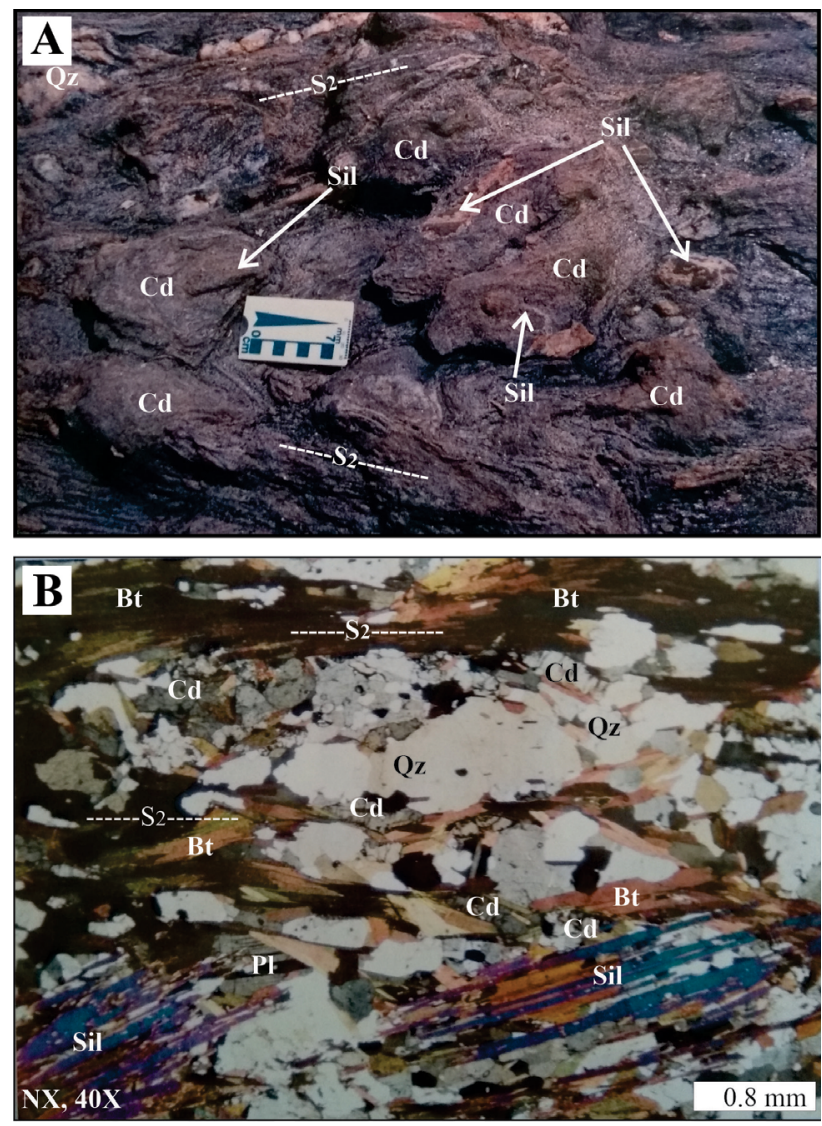

Figure 5. Biotite - cordierite - sillimanite schist in the cordierite $(\mathrm{Cd})+$ sillimanite (Sil) zone, with (A) porphyrolepidoblastic texture represented by megablasts of cordierite and sillimanite, syn- to late-foliation $\mathrm{S}_{2}$, beyond quartz $(\mathrm{Qz})$ vein in this foliation. (B) Photomicrography (crossed Nicols, 40X) characterizes growth, syn- to late- $S_{2}$, of cordierite and sillimanite from biotite $(\mathrm{Bt})$ and plagioclase (PI), beyond aggregates of quartz along $\mathrm{S}_{2}$.

andalusite and cordierite + sillimanite), indicating increased salinity. On the other hand, salinity was markedly decreased in the low-grade zones (biotite + garnet and biotite + chlorite + muscovite). Such differences are potentially explained by metamorphic reactions between minerals (e.g., the loss of $\mathrm{Cl}$ from biotite and apatite due to dehydration metamorphic devolatilization reactions) and probably infiltrating fluids genetically related to the Acari pluton emplaced during the peak of metamorphic episode $M_{2}$ (Souza, 1996). This suggests that a heterogeneous fluid was related to quartz vein formation in each metamorphic zone, despite the wide range of total homogenization temperatures.

\section{Total homogenization temperatures}

The Tht in quartz veins from all metamorphic zones shows a wide range of values (Table 1). The Tht for fluid inclusions 


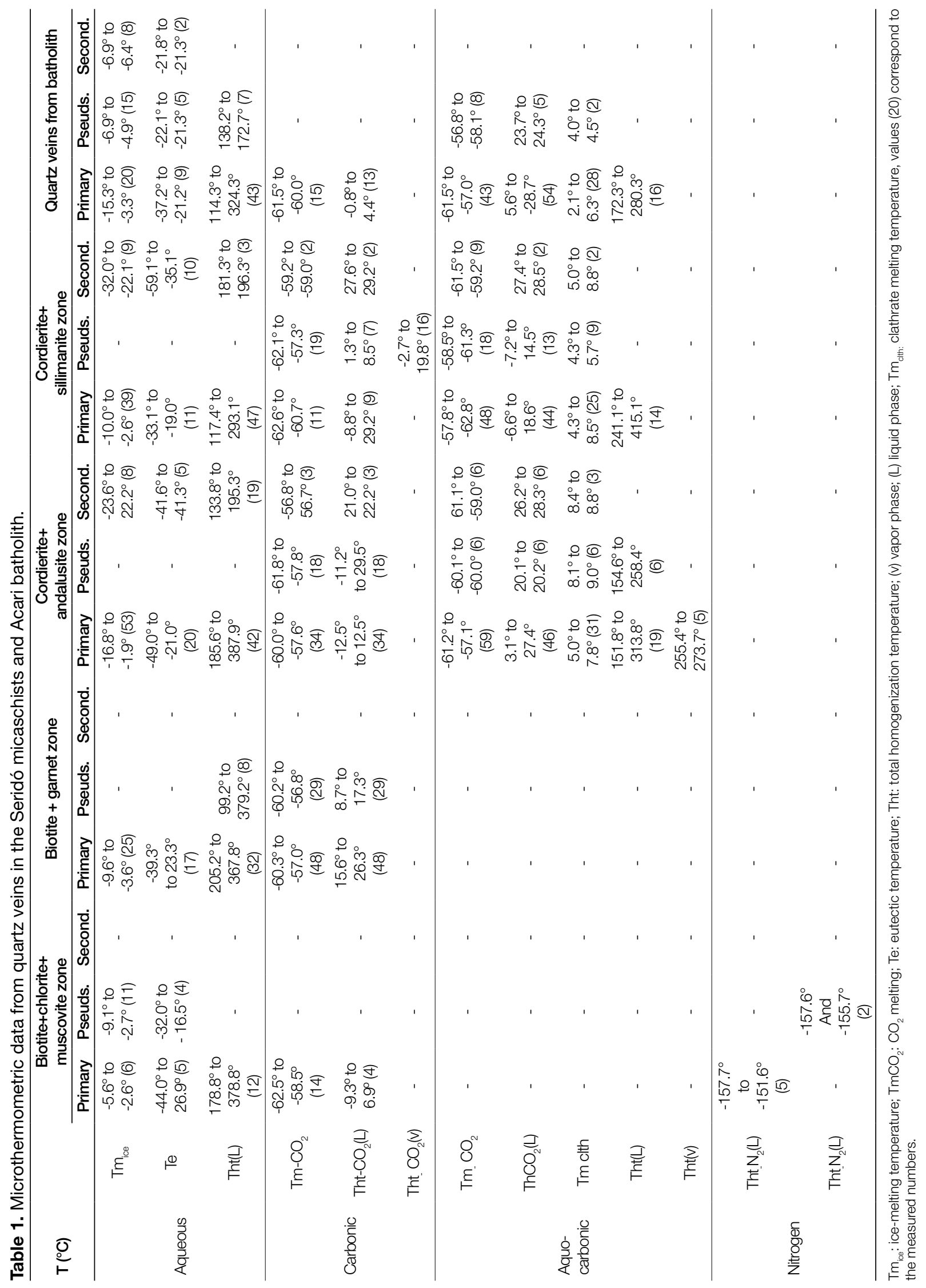



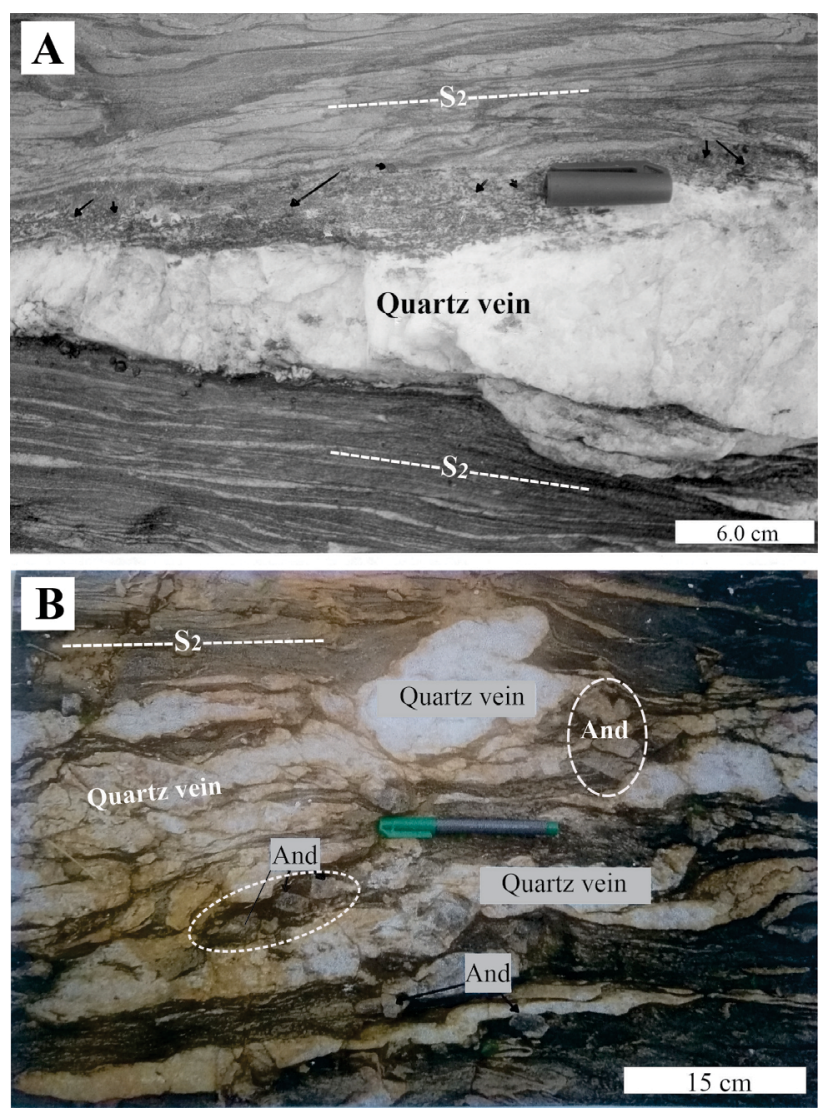

Figure 6. (A) Quartz vein along schistosity $S_{2}$ in the micaschist of the cordierite + andalusite zone and (B) a swarm of quartz veins $(\mathrm{Qz})$ in the micaschist, following the schistosity $S_{2}$, associated with growth of the blasts of andalusite (And) in the cordierite + andalusite zone.

in the four metamorphic zone ranges from 99.2 to $388^{\circ} \mathrm{C}$. Each zone shows the mode values of 207.3, 278, 197.8, and $223.4^{\circ} \mathrm{C}$, corresponding, respectively, to biotite + chlorite + muscovite, biotite + garnet, cordierite + andalusite, and cordierite + sillimanite zones (Figure 14). The broad range of homogenization temperatures may be due to post entrapment changes of the fluid inclusion volume and density reequilibration. The variation of fluid inclusion densities may be due to three reasons. First, inclusion leakage due to fluid overpressures up to $1 \mathrm{kbar}$, developed during progressive heating (Crawford and Hollister, 1986) from the syntectonic Acari granitic batholith. Second, the continuous cooling associated with decreased confining pressure due to exhumation (Vityk and Bodnar, 1995) of the micaschists. Third, the transpression deformation during or after vein emplacement (Souza, 1996). The quartz veins in the Seridó region were intensely strained with frequent recrystallization parallel to schistosity $\mathrm{S}_{2}$.

However, only a limited number of Th measurements from inclusions in quartz from the biotite + chlorite + muscovite zone were obtained due to the small size of the fluid inclusion. Finally, the differences in Th between inclusions in metamorphic zones are linked to some reequilibrations, mainly during the continuous heating and cooling of the Acari batholith and their thermal aureole.

\section{DISCUSSION}

The P-T conditions of vein emplacement are essential for relating the fluid inclusion compositions and the metamorphic reaction evolution. Assuming that chlorite + muscovite + biotite, biotite + garnet, cordierite + andalusite, and cordierite + sillimanite associations were synchronous with fluid inclusion entrapment, P-T conditions can be determined from biotite - garnet temperatures coupled with fluid inclusion isochores.

The isochore interception method of the $\mathrm{H}_{2} \mathrm{O}$ and $\mathrm{CO}_{2}$ systems was applied to estimate the P-T conditions of fluid inclusion trapping. The application of the isochores, using the Flincor 1.4 software (Brown, 1989), took into account the values of the mode of $\mathrm{Tm}_{\text {ice }}$ and Tht (aqueous fluids) and $\mathrm{ThCO}_{2}$ (carbonic fluid) of primary and pseudo-secondary inclusions from biotite + chlorite + muscovite, and biotite + garnet zones, and of primary inclusions only from cordierite + andalusite and cordierite + sillimanite zones. The equilibrium equation for the calculation of isochores was proposed by Brown and Lamb (1989) for the saline aqueous fluids $\left(\mathrm{H}_{2} \mathrm{O}-\mathrm{NaCl}\right)$ and by Bottinga and Richet (1981) for carbonic fluids. The thermal values for secondary aqueous and carbonic inclusions for cordierite + andalusite and cordierite + sillimanite zones were not estimated since the inclusions do not belong to the $\mathrm{H}_{2} \mathrm{O}-\mathrm{NaCl}$ system. Considering that fluid inclusions generally provide constraints only on minimum trapping pressures and temperatures, and applying the crossing of the isochores for fluid inclusions, minimal estimates were obtained as follows: pressures of 3.0 kbar for a temperature of $390^{\circ} \mathrm{C}$ in the biotite + chlorite + muscovite zone; $1.5 \mathrm{kbar}$ for a temperature of $395^{\circ} \mathrm{C}$ in the biotite + garnet zone; $3.8 \mathrm{kbar}$ for a temperature of $410^{\circ} \mathrm{C}$ in the cordierite + andalusite zone; and $3.5 \mathrm{kbar}$ for a temperature of $460^{\circ} \mathrm{C}$ in the cordierite + sillimanite zone (Figure 15). These parameters are analogous and consistent with the calculated pressures and temperatures of $\mathrm{M}_{2}$ using the biotite + garnet thermometer and garnet + plagioclase barometer (Souza, 1996).

Results of quartz veins fluid inclusions evidence the aqua-carbonic, carbonic, and aqueous fluids in the high-temperature metamorphic zones. In contrast, only carbonic, aqueous and $\mathrm{N}_{2}$-rich fluids were identified in the low-temperature zones. Samples of quartz veins hosted in the Acari granite, in turn, provided aqueous, carbonic, and aqua-carbonic types. The petrographic and microthermometric similarities found in 

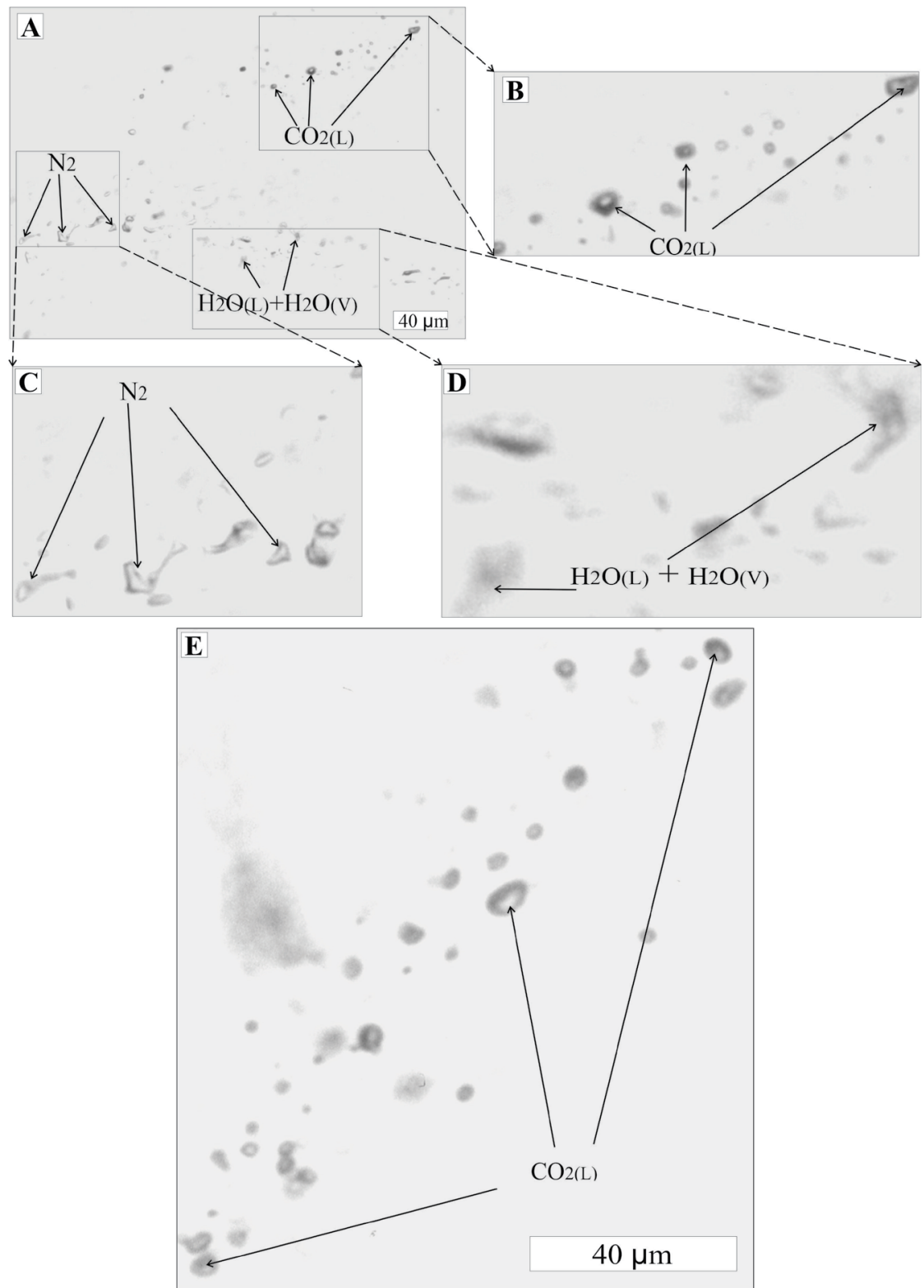

Figure 7. Fluid inclusions in quartz vein, in the biotite + chlorite + muscovite metamorphic zone. (A) Primary/early $\mathrm{H}_{2} \mathrm{O}, \mathrm{CO}_{2}$, $\mathrm{N}_{2}$ fluid inclusions in quartz vein. (B, C and D) Details from image (A). (E) Pseudo-secondary trail $\mathrm{CO}_{2}$ fluid inclusions. (250X).

the fluid inclusions of quartz veins from the Acari granite and high-temperature micaschists (cordierite + andalusite and cordierite + sillimanite zones) suggest that the fluid from the granite could have contributed to the mineralogical transformations that formed the thermal aureole in the host micaschists. The main aspects of fluid inclusions in quartz veins from metamorphic zones of micaschists and granite include the fact that the size of fluid inclusions progressively increases towards higher-temperature metamorphic zones and, in consequence, to the Acari granite; salinity of the aqueous fluid also increases towards higher-temperature metamorphic zones, and the mode values of $\mathrm{Tm}_{\text {ice }}$ $=-3.8,-5.5,-5.6$, and $-7.3^{\circ} \mathrm{C}$ correspond, respectively, to the biotite + chlorite + muscovite, biotite + garnet, cordierite + andalusite, and cordierite + sillimanite zones. Such increase in salinity is evidenced by salt cubes in the aqueous inclusions of the quartz veins from higher-temperature metamorphic zones and also from the Acari granite. Lastly, the low temperatures of Tfg measured in the secondary aqueous inclusions from the cordierite + andalusite and 


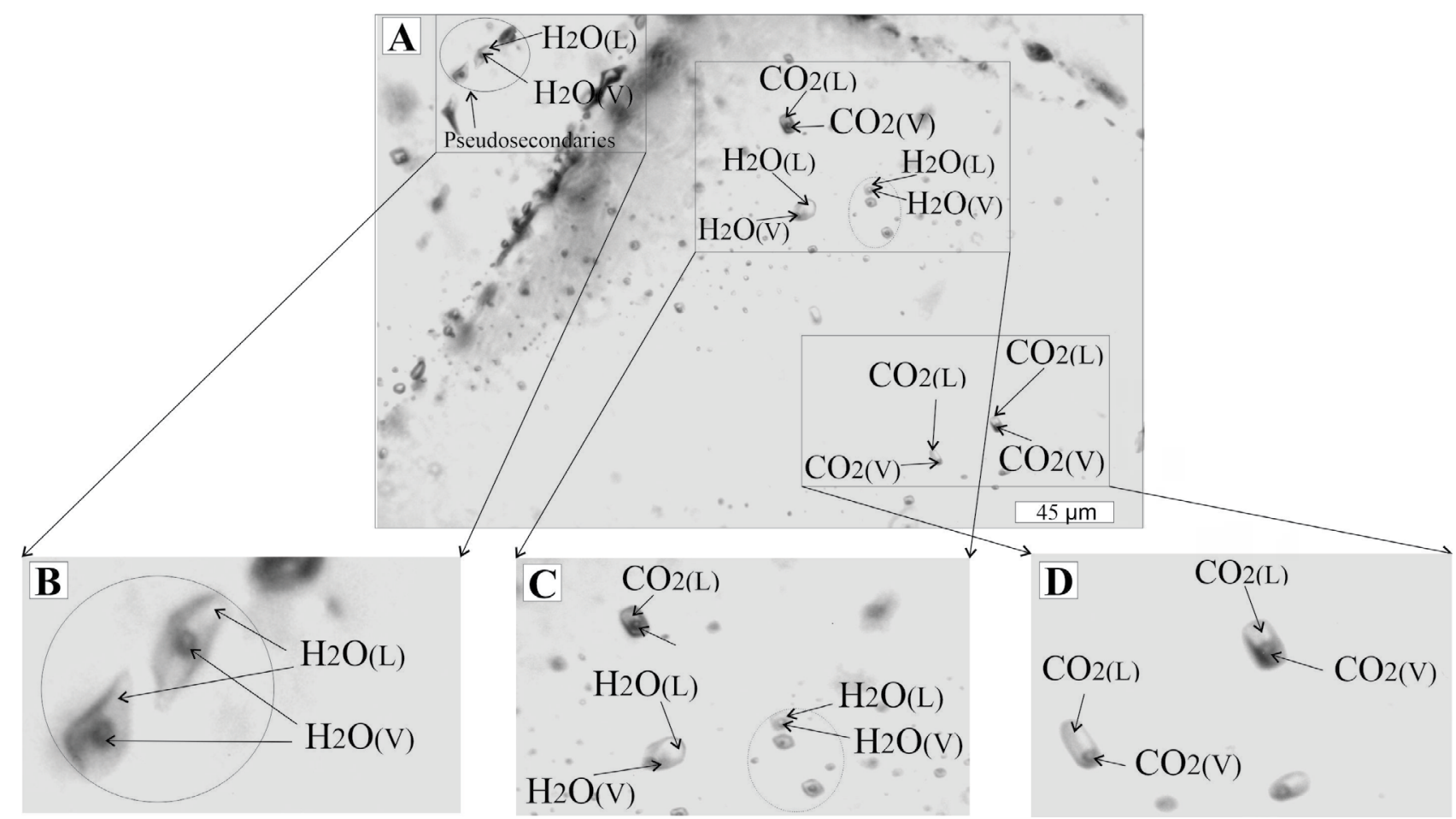

Figure 8. (A) Primary/early, biphasic $\mathrm{H}_{2} \mathrm{O}, \mathrm{CO}_{2}$ and pseudo-secondary aqueous fluid inclusions in quartz vein, in the biotite + garnet metamorphic zone. (250X). (B, C and D) Details from image (A).

cordierite + sillimanite zones indicate a chemical system composed of $\mathrm{H}_{2} \mathrm{O}-\mathrm{NaCl}(\mathrm{KCl})-\mathrm{MgCl}_{2}-\mathrm{FeCl}_{2}-\mathrm{CaCl}_{2}$. This suggests an efficient process of dissolution of the biotite and plagioclase and, mainly, the release of $\mathrm{Na}^{+}, \mathrm{Ca}^{2+}, \mathrm{Mg}^{2+}$, and $\mathrm{Fe}^{2+}$ into the fluid phase, which assists in forming the index minerals, such as cordierite, andalusite, sillimanite, and quartz veins, according to the reactions that follow (Souza, 1996):

plagioclase $(25 \% \mathrm{An})+\mathrm{H}^{+} \leftrightarrow$ andalusite/sillimanite + quartz (vein) $+\mathrm{Na}^{+}+\mathrm{Ca}^{2+}+\mathrm{H}_{2} \mathrm{O}$;

$6 \mathrm{NaAlSi}_{3} \mathrm{O}_{8}+2 \mathrm{CaAl}_{2} \mathrm{Si}_{2} \mathrm{O}_{8}+10 \mathrm{H}^{+}=5 \mathrm{Al}_{2} \mathrm{SiO}_{5}+17 \mathrm{SiO}_{2}$ (vein) $+6 \mathrm{Na}^{+}+2 \mathrm{Ca}^{2+}+5 \mathrm{H}_{2} \mathrm{O}$;

biotite + plagioclase $(25 \% \mathrm{An})+\mathrm{H}^{+} \leftrightarrow$ cordierite + ilmenite + quartz (vein) $+\mathrm{Na}^{+}+\mathrm{Ca}^{2+}+\mathrm{K}^{+}+\mathrm{Fe}^{2+}+\mathrm{H}_{2} \mathrm{O}$;

$\mathrm{K}_{2}\left(\mathrm{Mg}_{0.48}, \mathrm{Fe}_{0.48}, \mathrm{Ti}_{0.04}\right)_{5.5} \mathrm{Al}_{3} \mathrm{Si}_{5.5} \mathrm{O}_{20}(\mathrm{OH})_{4}+3.27 \mathrm{NaAlSi}_{3} \mathrm{O}_{8}$ $+1.09 \mathrm{CaAl}_{2} \mathrm{Si}_{2} \mathrm{O}_{8}+8.69 \mathrm{H}^{+} \leftrightarrow 2.11\left(\mathrm{Fe}_{0.4}, \mathrm{Mg}_{0.6}\right)_{2} \mathrm{Al}_{4} \mathrm{Si}_{5} \mathrm{O}_{18}$ $+0.22 \mathrm{FeTiO}_{3}+6.94 \mathrm{SiO}_{2}$ (vein) $+3.27 \mathrm{Na}^{+}+1.09 \mathrm{Ca}^{2+}+$ $2 \mathrm{~K}^{+}+0.62 \mathrm{Fe}^{2+}+6.36 \mathrm{H}_{2} \mathrm{O}$;

biotite +57.9 plagioclase $(25 \% \mathrm{An})+51.2 \mathrm{H}^{+}+11 \mathrm{Fe}^{2+} \leftrightarrow$ 8.25 staurolite +132.4 quartz (vein) $+2 \mathrm{~K}^{+}+13.3 \mathrm{Ca}^{++}+$ $44.6 \mathrm{Na}^{+}+23.5 \mathrm{H}_{2} \mathrm{O}$;
$\mathrm{K}_{2}\left(\mathrm{Mg}_{0.48}, \mathrm{Fe}_{0.52}\right)_{5.5} \mathrm{Al}_{3} \mathrm{Si}_{5.5} \mathrm{O}_{20}(\mathrm{OH})_{4}+13.3 \mathrm{CaAl}_{2} \mathrm{Si}_{2} \mathrm{O}_{8}+$ $44.6 \mathrm{Na} \mathrm{Al}_{2} \mathrm{Si}_{3} \mathrm{O}_{8}+51.2 \mathrm{H}^{+}+11 \mathrm{Fe}^{2+} \leftrightarrow 8.25\left(\mathrm{Fe}_{0.84}, \mathrm{Mg}_{0.16}\right)_{2}$ $\mathrm{Al}_{9} \mathrm{Si}_{4} \mathrm{O}_{23}(\mathrm{OH})+132.4 \mathrm{SiO}_{2}$ (vein) $+2 \mathrm{~K}^{+}+13.3 \mathrm{Ca}^{2+}+44.6$ $\mathrm{Na}^{+}+23.5 \mathrm{H}_{2} \mathrm{O}$.

All the aqueous, carbonic, and aqua-carbonic fluids in the quartz veins from the higher-temperature metamorphic zones could be assigned predominantly to an initial, homogeneous, carbonic fluid. This initial fluid would be originated from deep crustal sources (e.g., from the underlying marble of the Jucurutu Formation), and its upward migration could be related to the emplacement, at depths of $\sim 18$ to $19 \mathrm{~km}$ (Campos et al., 2016), of the Acari batholith. Sirbescu and Nabelek (2003), Bhattacharya et al. (2014) and Goldfarb and Groves (2015) support this hypothesis. This fluid could be mixed with an aqueous fluid from metamorphic reactions in the micaschists and batholith's magmatic fluids. This mixture may have been subjected to the immiscibility mechanism, allowing simultaneous trapping of aqueous (variable salinity), carbonic, and aqua-carbonic inclusions with variable volumetric $(10-90 \%)$ ratios in the high-temperature metamorphic zones. The absence of aqua-carbonic inclusions in the lower-temperature zones (biotite + chlorite + muscovite and biotite + garnet) could be explained in two ways: firstly, the mixture and immiscibility of fluids in these zones were not achieved; thus, the carbonic inclusions would be sourced 


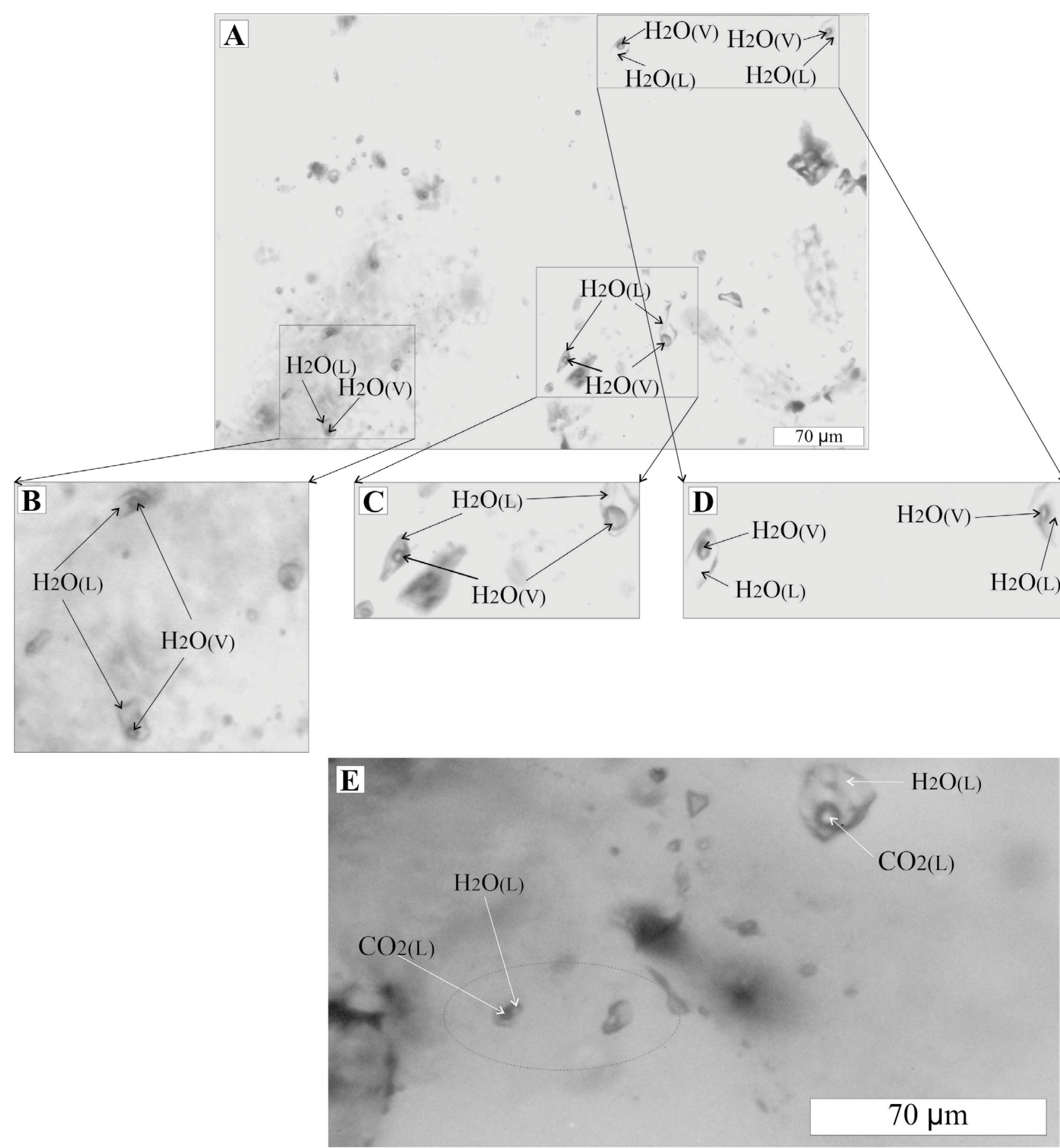

Figure 9. Photomicrographs of fluid inclusions in quartz vein in the cordierite + andalusite metamorphic zone showing (A) primary/precocious, biphasic, aqua-saline fluid inclusions. (B, C and D) Details from image (A), 250X. (E) represents aqua-carbonic fluid inclusions (250X).

from a homogeneous carbonic fluid situated in the deeper crust, while the aqueous inclusions of low salinity would be derived from magmatic fluid and/or metamorphic reactions in the micaschists. This would explain the absence of the same population of aqueous and carbonic inclusions in the biotite + chlorite + muscovite zone. Secondly, the aqueous and carbonic inclusions coexisting in the same population in the biotite + garnet zone. Then, it is possible to estimate 


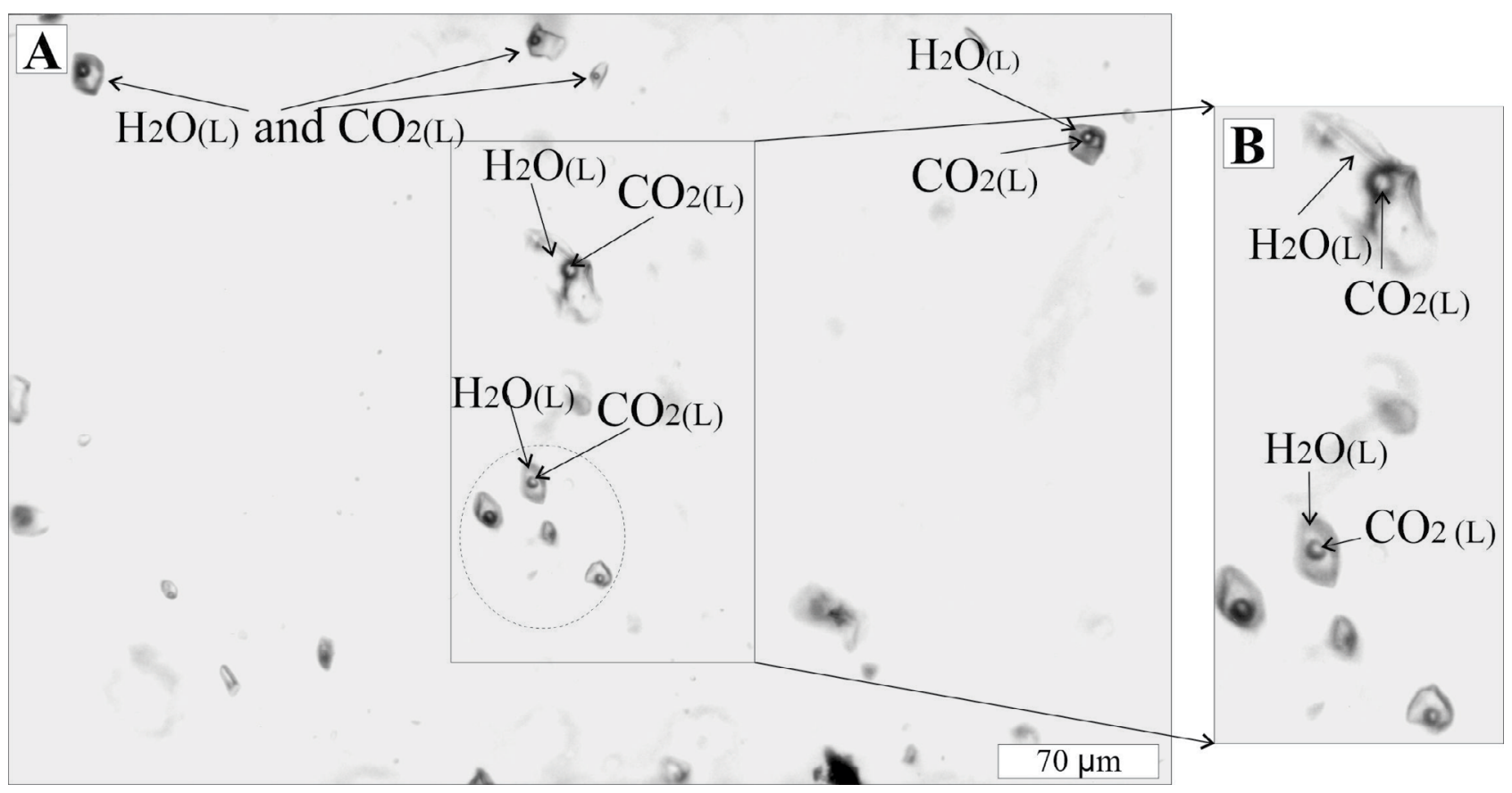

Figure 10. Photomicrography showing $(A)$ primary/early, biphasic, aqua-carbonic fluid inclusions from quartz vein in the cordierite + sillimanite metamorphic zone (250X). (B) Details from image (A).

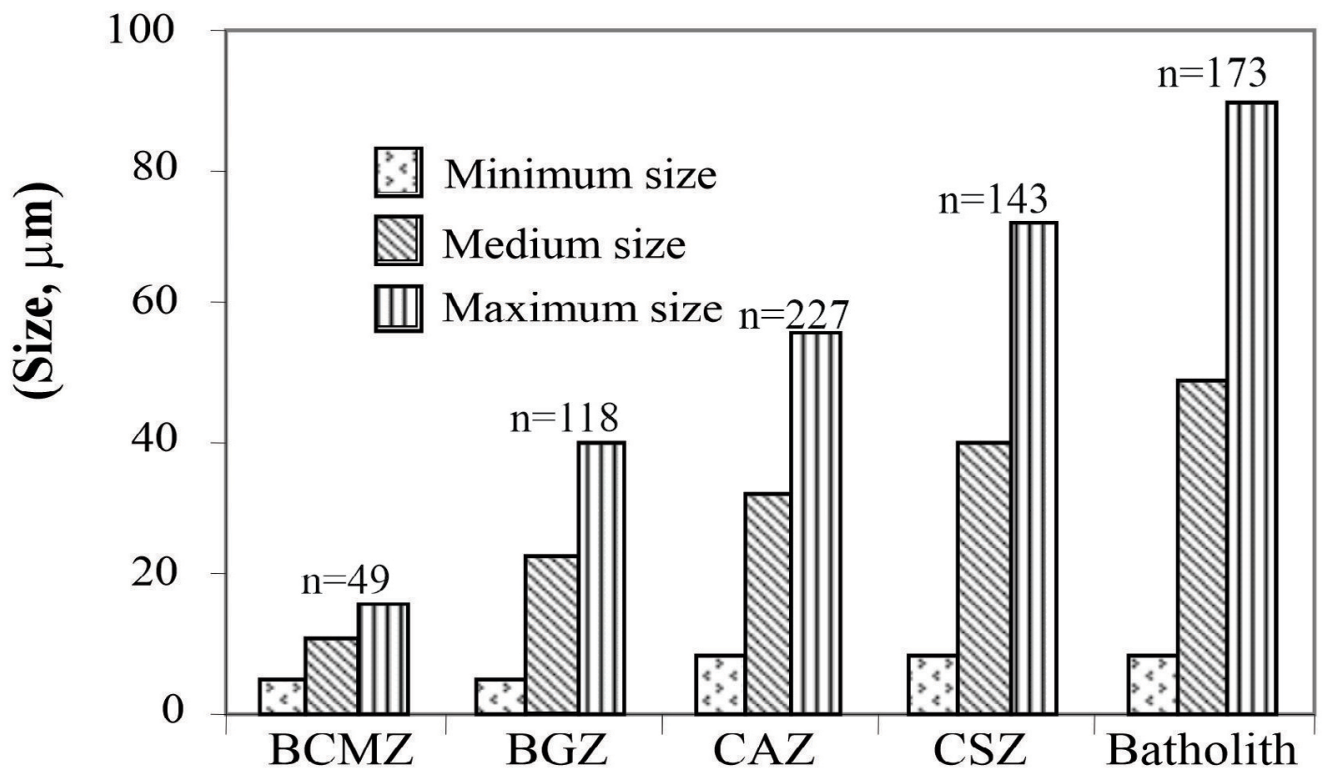

BCMZ: biotite + chlorite + muscovite zone; BGZ: biotite + garnet zone; CAZ: cordierite + andalusite zone; CSZ: cordierite + sillimanite zone; n: number of fluid inclusions considered.

Figure 11. Comparing the size of fluid inclusions from quartz veins in the thermal aureole of the Seridó micaschists and Acari batholith. The size of fluid inclusions increases progressively towards high-grade metamorphic zones and Acari granitic batholith.

that the aqua-carbonic $\pm\left(\mathrm{N}_{2} \pm \mathrm{CH}_{4}\right)$ fluids would also coexist, at least, in this last metamorphic zone, and that the individualization of the carbonic and aqua-saline inclusions was affected by the deformation.
Crawford and Hollister (1986) posit that post-metamorphic extraction of $\mathrm{H}_{2} \mathrm{O}$ from the $\mathrm{H}_{2} \mathrm{O}+\mathrm{CO}_{2}$ mixture included removing the aqueous phase along micro fissures that cross the aqua-carbonic inclusions. According to Hendel and 

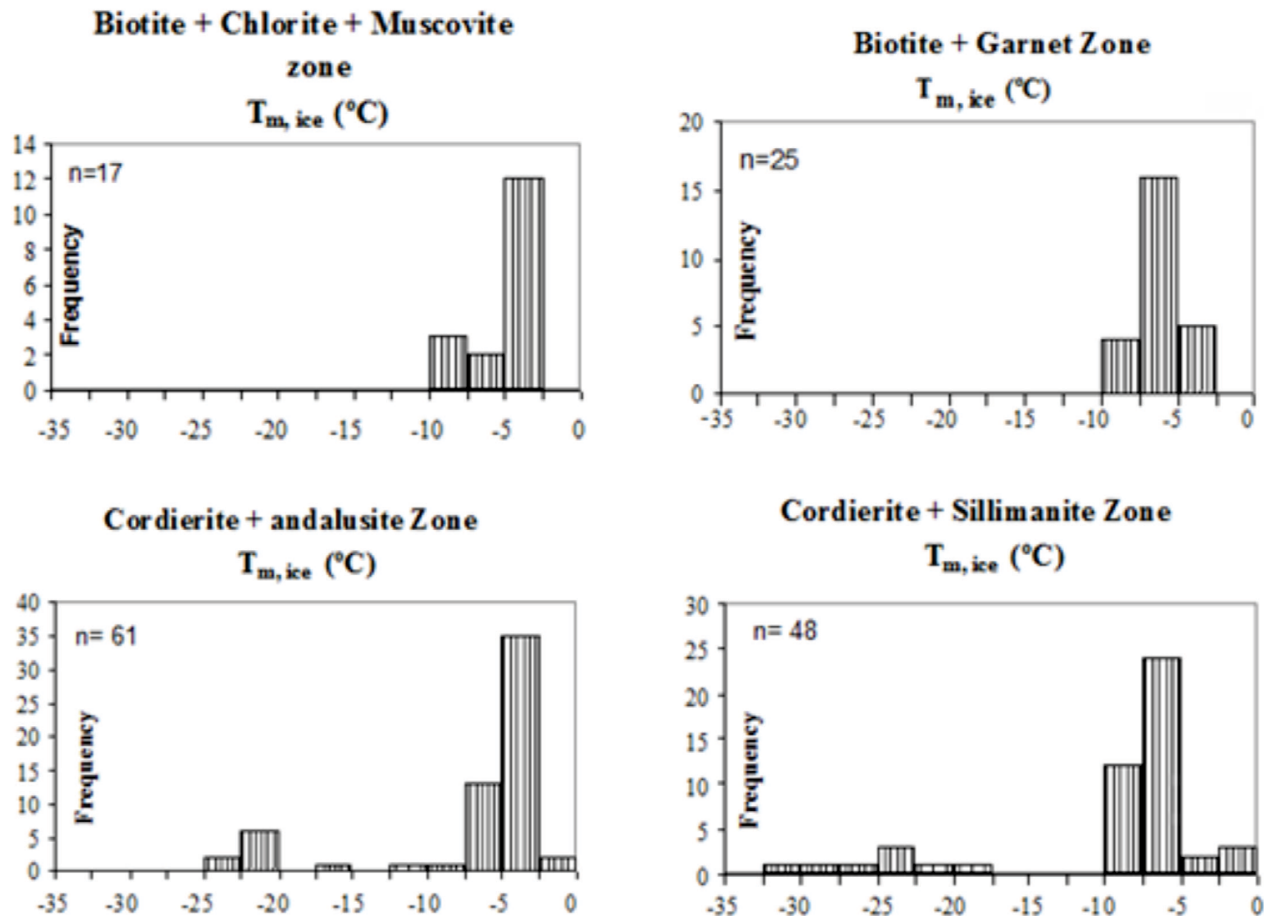

Granitic Batholith

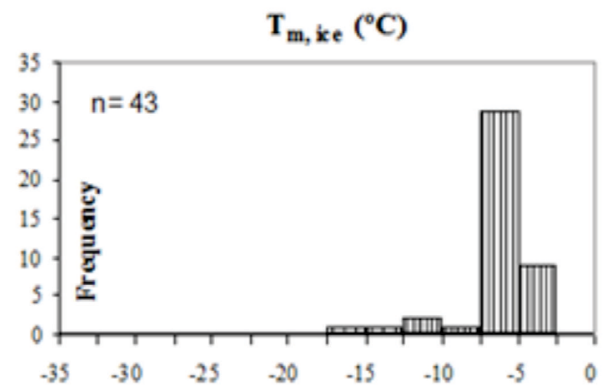

Figure 12. Ice-melting temperatures of aqueous fluid inclusions from quartz veins in the thermal aureole of the Seridó micaschists and Acari batholith.

Hollister (1981), the trapping of nearly pure $\mathrm{CO}_{2}$ by a system composed of two phases is based on the immiscibility of the $\mathrm{CO}_{2}+\mathrm{H}_{2} \mathrm{O}$ fluid. This must occur in the greenschist facies and low amphibolite facies. According to Hollister (1990), ductile deformation of the quartz associated with hydraulic micro fissures possibly constitutes the physical mechanism for generating pure $\mathrm{CO}_{2}$ inclusions using the withdrawal of water from homogeneous inclusions $\left(\mathrm{CO}_{2}+\right.$ $\mathrm{H}_{2} \mathrm{O}$ ). Due to ductile deformation, water loss leads to the enrichment of $\mathrm{CO}_{2}$ fluid beyond that of other components. These components include $\mathrm{NaCl}, \mathrm{CaCl}_{2}$, and $\mathrm{KCl}$, as well as $\mathrm{CH}_{4}$ and $\mathrm{N}_{2}$. The deformation that affected the quartz veins along the thermal aureole could subsequently provide the total separation of $\mathrm{CO}_{2}$ from $\mathrm{H}_{2} \mathrm{O}$ in the fluid inclusions found in the low-temperature metamorphic zones.

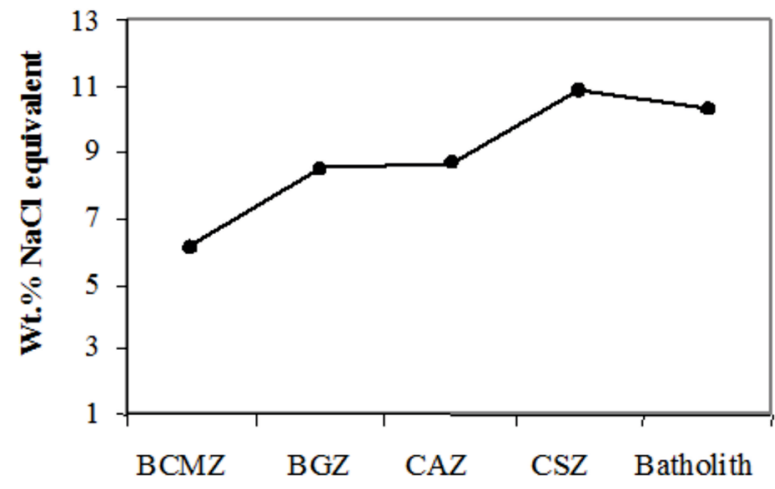

BCMZ: biotite + chlorite + muscovite zone; BGZ: biotite + garnet zone; CAZ: cordierite + andalusite zone; CSZ: cordierite + sillimanite zone.

Figure 13. Variation in salinity of primary/precocious and pseudo-secondary aqueous fluid inclusions in quartz veins from thermal aureole of the Seridó micaschists around Acari batholith. 

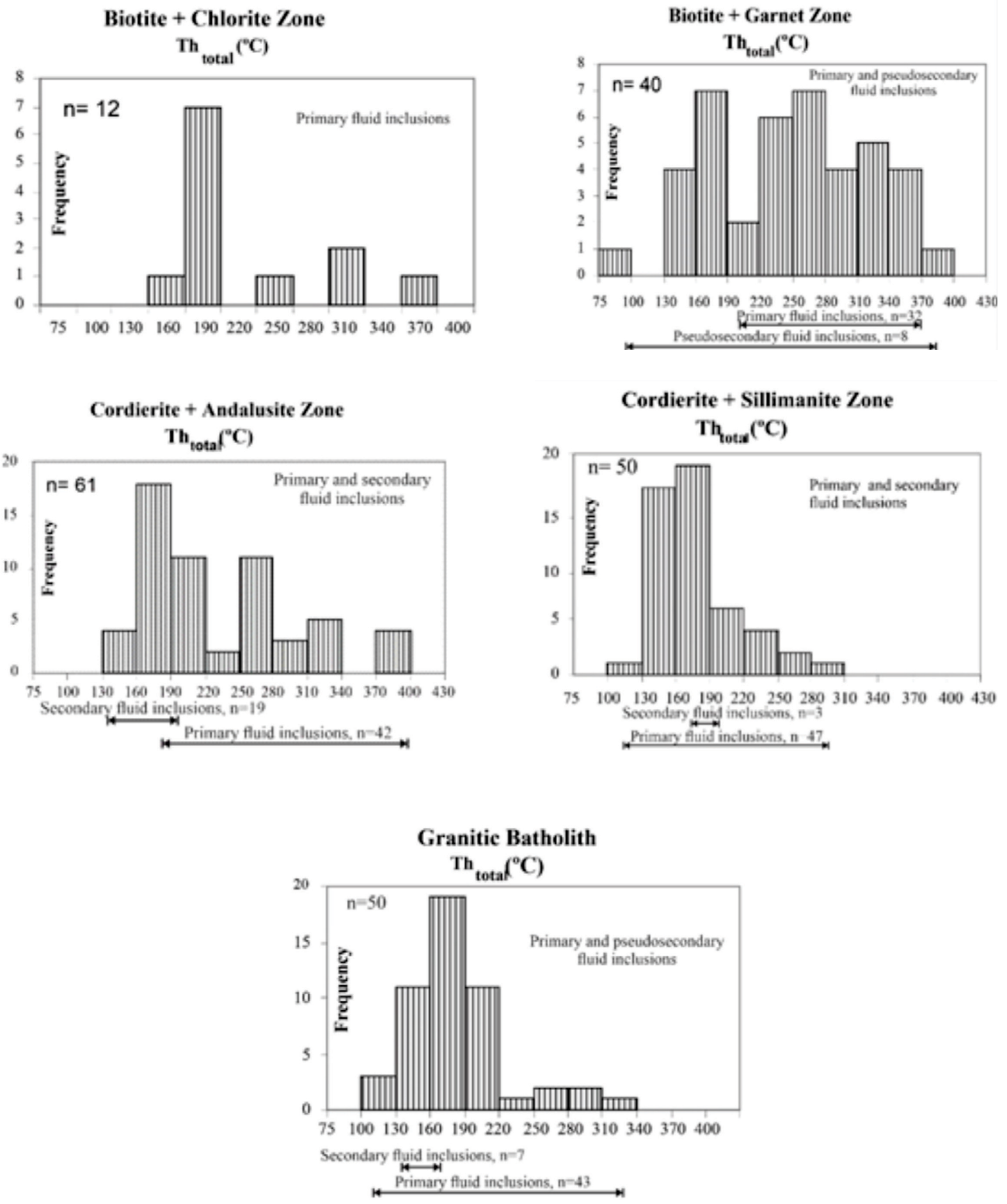

Figure 14. Total homogenization temperatures (Tht) of aqueous fluid inclusions from quartz veins in the thermal aureole of the Seridó micaschists and Acari batholith.

\section{CONCLUSIONS}

The P-T conditions agree with the quartz vein formation and fluid entrapment associated with the generation of the thermal aureole. When considered collectively, field observations, calculated P-T, total homogenization temperatures, and isochores from primary and pseudo-secondary fluid inclusions indicate that the quartz veins were formed during 
A

Biotite + Chlorite + muscovite Zone

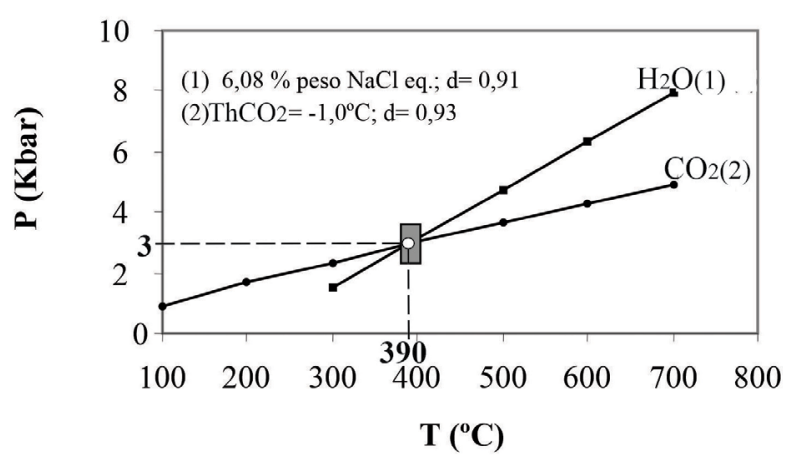

C

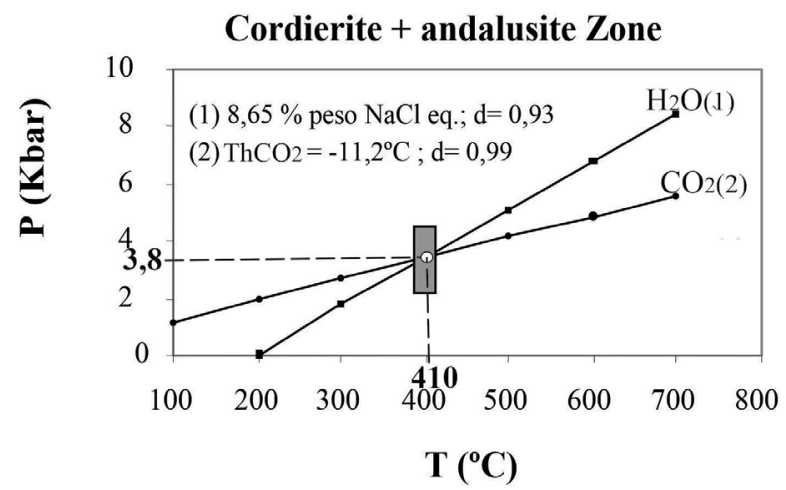

B

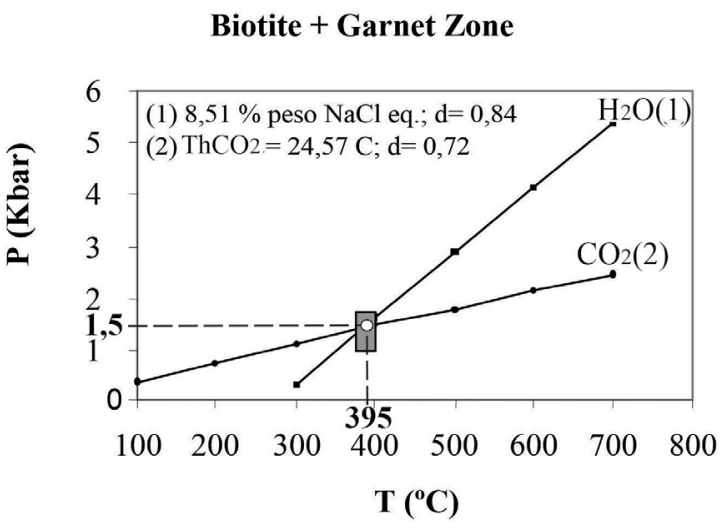

D

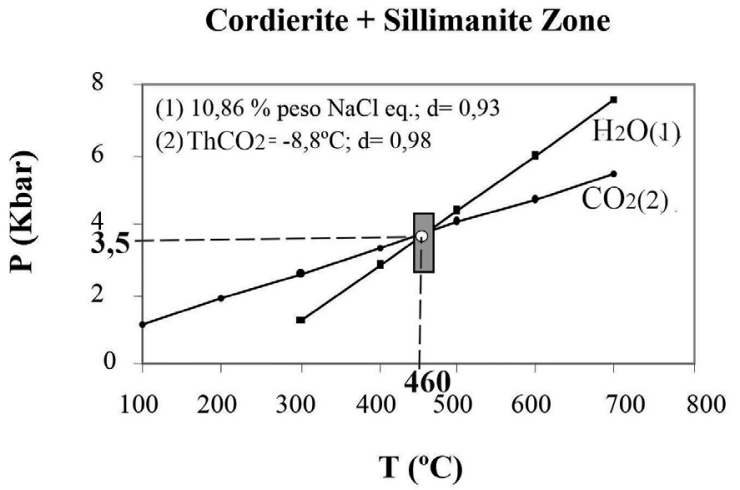

Figure 15. Isochores for modal Th showing the $\mathrm{P}-\mathrm{T}$ conditions of trapping for $\mathrm{H}_{2} \mathrm{O}$ and $\mathrm{CO}_{2}$-rich fluid inclusions from (A) biotite + chlorite + muscovite, (B) biotite + garnet (C) cordierite + andalusite, and (D) cordierite + sillimanite zones of the Seridó micaschists around Acari batholith. The isochores were performed with the Flincor 1.4 software (Brown, 1989).

a large temperature range along thermal metamorphic aureole from peak metamorphic temperatures of $600^{\circ} \mathrm{C}$ (cordierite + sillimanite) to $400^{\circ} \mathrm{C}$ (biotite + chlorite + muscovite).

This paper concludes that the efficient dissolution process of the biotite and plagioclase seem to be intensively involved in the metasomatic process responsible for forming the metamorphic aureole. The origin of aqueous fluid could be related to the dehydration reactions of the Serido micaschists and most likely to the circulation of magmatic fluid from the Acari batholith.

The carbonic fluid is probably related to the metamorphic reactions of the metacarbonate rocks underlying these micaschists. Graphite was not found in the micaschists, which could react with $\mathrm{H}_{2} \mathrm{O}$ to produce $\mathrm{CO}_{2}$. In turn, the granite batholith could have contributed with aqua-carbonic, carbonic, and aqueous fluids since these fluids are contained in the fluid inclusions of the veins housed in the granitic massif.
The presence of $\mathrm{N}_{2}$ in the biotite + chlorite + muscovite zone is a matter of discussion. Still, its origin could likely be related to a fluid phase from clay minerals delivered by pelitic sediment in the initial stages of the regional metamorphism.

The variability in quartz vein inclusion salinity from the thermal aureole of the Seridó micaschists is mainly linked to devolatilization metamorphic reactions. Furthermore, the Acari batholith could have contributed to increased salinity in the fluids trapped by such veins. This is supported by the presence of aqua-saline fluid inclusions in quartz veins within the granitic massif. Finally, there was a marked increase in fluid salinity towards the higher-temperature metamorphic zones due to the dissolution reactions of plagioclases and biotites, in addition to the very likely contribution of fluids from granitic batholith. Furthermore, in the higher-temperature metamorphic zones, fluid inclusion saturation allowed precipitation of salt crystals. 


\section{ACKNOWLEDGMENTS}

The authors thank Coordenação de Aperfeiçoamento de Pessoal de Ensino Superior (CAPES) for having financially supported this research paper through Ph.D. and MsC scholarships granted to the first and second author, respectively. We also thank the anonymous reviewers, Professor Francisco Hilário R. Bezerra, and Samantha Nagle C. de Moura, who significantly improved the final version of this manuscript.

\section{REFERENCES}

Archanjo, C. J., Olivier, P., Boucher, J. L. (1992). Plutons granitiques du Seridó (NE Brésil) écoulement magmatique parallèle à la chaîne révélé par leur anisotropie magnétique. Bulletin de la Société Géologique de France, 163(4), 509520. Available at: https://pubs.geoscienceworld.org/sgf/bsgf/ article/163/4/509/122609/plutons-granitiques-du-serido-ne-dubresil. Accessed on: Sep 8, 2021.

Archanjo, C. J., Viegas, L. G. F., Hollanda, M. H. B. M., Souza L. C., Liu, D. (2013). Timing of the HT/LP transpression in the Neoproterozoic Seridó Belt (Borborema Province, Brazil): Constraints from U-Pb (SHRIMP) geochronology and implications for the connections between NE Brazil and West Africa. Gondwana Research, 23(2), 701-714. https:// doi.org/10.1016/j.gr.2012.05.005

Bhattacharya, S., Panigrahi, M. K., Jayananda, M. (2014). Mineral thermobarometry and fluid inclusion studies on the Closepet granite, Eastern Dharwar Craton, south India: Implications to emplacement and evolution of late-stage fluid. Journal of Asian Earth Sciences, 91, 1-18. https:// doi.org/10.1016/j.jseaes.2014.04.004

Bottinga, Y., Richet, P. (1981). High pressure and temperature equation of state and calculation of the thermodynamic properties of gaseous carbon dioxide. American Journal of Science, 281(5), 615-660. https://doi.org/10.2475/ ajs.281.5.615

Brown, P. E. (1989). FLINCOR: a microcomputer program for the reduction and investigation of fluid-inclusion data. University of Wisconsin, Madison. American Mineralogist, 74(11), 1390-1393. Available at: https://www.researchgate. net/publication/279895263_FLINCOR_a_microcomputer_ program_for_the_reduction_and_investigation_of_fluidinclusion_data. Accessed on: Sep 8, 2021.

Brown, P. E., Lamb, W. N. (1989). P-V-T properties of fluids in the system $\mathrm{H}_{2} \mathrm{O}-\mathrm{CO}_{2}-\mathrm{NaCl}$ : New graphical presentations and implications for fluid inclusion studies. Geochimica et Cosmochimica Acta, 53(6), 1209-1221. https://doi. org/10.1016/0016-7037(89)90057-4

Bucher, K., Frey, M. (1994). Petrogenesis of metamorphic rocks. $6^{\text {a }}$ ed. Berlin: Springer-Verlag, 319 p. https://doi. org/10.1007/978-3-662-03000-4

Caby, R. (1989). Precambrian terranes of Benin-Nigeria and northeast Brazil and late proterozoic South Atlantic fit. In: R. D. Dallmeyer (Ed.), Terranes in the Circum-Atlantic Paleozoic Orogens, v. 230, p. 145-158. Geological Society of America, Special Paper. https://doi.org/10.1130/SPE230-p145

Campos, B. C. S., Vilalva, F. C. J., Nascimento, M. A. L., Galindo, A. C. (2016). Crystallization conditions of porphyritic high-K calc-alkaline granitoids in the extreme northeastern Borborema Province, NE Brazil, and geodynamic implications. Journal of South American Earth Sciences, 70, 224-236. https://doi.org/10.1016/j.jsames.2016.05.010

Carlson, W. D., Hixon, J. D., Garber J. M., Bodnar, R. J. (2015). Controls on metamorphic equilibration: the importance of intergranular solubilities mediated by fluid composition. Journal of Metamorphic Geology, 33(2), 123-146. https:// doi.org/10.1111/jmg.12113

Crawford, M. L., Hollister, L. S. (1986). Metamorphic fluids: the evidence from fluid inclusions. In: V. Walther, B. J. Wood (Eds), Fluid-rock interactions during metamorphism, v. 5, p. 1-35. New York: Spring-Verlag. https://doi. org/10.1007/978-1-4612-4896-5_1

Dantas, E. L. (1997). Geocronologia U-Pb e Sm-Nd de terrenos arqueanos e paleoproterozoicos do maciço Caldas Brandão, NE do Brasil. Thesis (Doctorate). Rio Claro: Instituto de Geociências - UNESP, 218 p.

Dantas, E. L., Van Schmus, W. R., Hackspacher, P. C., Fetter, A. H., Brito Neves, B. B., Cordani, U., Nutman, A. P., Williams, I. S. (2004). The 3.4-3.5 São José de Campestre massif, NE Brazil: remnants of the oldest crust in South America. Precambrian Research, 130(1-4), 113-137. https:// doi.org/10.1016/j.precamres.2003.11.002

Goldfarb, R. J., Groves, D. I. (2015). Orogenic gold: Common or evolving fluid and metal sources through time. Lithos, 233, 2-26. https://doi.org/10.1016/j.lithos.2015.07.011

Goldstein, R. H., Reynolds, T. J. (1994). Systematics of fluid inclusions in diagenetic minerals. USA, Society for Sedimentary Geology, v. 31, 199 p. https://doi.org/10.2110/scn.94.31 
Hendel, E. M., Hollister, L. S. (1981). An empirical solvus for $\mathrm{CO}_{2}-\mathrm{H}_{2} \mathrm{O}-2.6$ wt.\% salt. Geochimica et Cosmochimica Acta, 45(2), 225-228. https://doi.org/10.1016/0016-7037(81)90166-6

Hollanda, M. H. B. M., Archanjo, C. J., Bautista, J. R., Souza, L. C. (2015). Detrital zircon ages and Nd isotope compositions of the Seridó and Lavras da Mangabeira basins (Borborema Province, NE Brazil): Evidence for exhumation and recycling associated with a major shift in sedimentary provenance. Precambrian Research, 258, 186-207. https:// doi.org/10.1016/j.precamres.2014.12.009

Hollister, L. S. (1990). Enrichment of $\mathrm{CO}_{2}$ in fluid inclusion in quartz by removal of $\mathrm{H}_{2} \mathrm{O}$ during crystal-plastic deformation. Journal of Structural Geology, 12(7), 895-901. https://doi. org/10.1016/0191-8141(90)90062-4

Legrand, J. M., Martins Sá, J. (1986). Geotermometria, geobarometria e zonação metamórfica do sinforme de Cruzeta (RN), Brasil. XXXIV Congresso Brasileiro de Geologia. Anais, 4, 1407-1423. Goiânia: SBG.

Leterrier, J., Jardim de Sá, E. F., Bertrand, J. M., Pin, C. (1994). Ages U-Pb sur zircon de granitoïdes "brasilianos" de la ceinture Seridó (Province Borborema, NE Brésil). Comptes Rendus de l'Académie des Sciences, 318(11), 1505-1511.

Lima, E. S. (1986). Metamorphism and tectonic evolution in the Seridó region, Northeasthern Brazil. PhD Thesis. California: University of California, $208 \mathrm{p}$.

Luiz Silva, W. (1995). Estudos da interação fluido-rocha na área do depósito aurífero São Francisco, Currais Novos $(R N)$ : Aspectos estruturais e metamórficos. Dissertation (Master's Degree). Rio Claro: UNESP, 183 p.

Miyashiro, A. (1994). Metamorphic Petrology. London: University College London Press, 404 p.

Roedder, E. (1984). Fluid inclusions. Reviews in Mineralogy. Reston: Minerological Society of America, v. 12,644 p.

Salim, J. (1993). Géologie, pétrologie et géochimie des skarns à scheelite de la mine Brejui, Currais Novos, NE du Brésil. Thesis (Doctorate). Louvain-la-Neuve, Belgique: Lab. de Géologie et Minéralogie - Université Catholique de Louvain, 272 p. Available at: https://hdl.handle.net/2078.1/205426. Accessed on: Sep 8, 2021.

Sirbescu, M. C., Nabelek, P. I. (2003). Crystallization conditions and evolution of magmatic fluids in the Harney
Peak Granite and associated pegmatites, Black Hills, South Dakota - Evidence from fluid inclusions. Geochimica et Cosmochimica Acta, 67(13), 2443-2465. https://doi. org/10.1016/S0016-7037(02)01408-4

Souza, L. C. (1996). Zonéographie métamorphique, chimie des minéraux, pétrochimie, géochronologie $40 \mathrm{Ar} / 39 \mathrm{Ar}$ et histoire P-T-t des micaschistes englobant le massif gabbrogranitique d'Acari (Brasiliano), ceinture mobile du Seridó (NE du Brésil). Thesis (Doctorate). Louvain-la-Neuve, Belgique: Laboratoire de Minéralogie et Géologie-Université Catholique de Louvain, 345 p.

Souza, L. C., Carvalho, A. C. (2015). Equilíbrios metamórficos a luz da solubilidade intergranular mediante fluidos hidrotermais nos micaxistos da Faixa Seridó, NE do Brasil. XXVI Simpósio de Geologia do Nordeste, 24, p. 92. Natal: SBG, Regional Nordeste.

Souza, L. C., Legrand, J. M., Verkaeren, J. (2007). Metamorfismo térmico nos micaxistos Seridó em torno do batólito de Acari (RN), nordeste do Brasil: Química mineral de ilmenitas e turmalinas. Revista Estudos Geológicos, 17(2), 71-84. Available at: http:// www3.ufpe.br/estudosgeologicos/. Accessed on: Sep 8, 2021.

Souza, L. C, Verkaeren, J., Legrand, J. M., Sonnet, P. (1996). Le métamorphisme et la participation des fluides dans les micaschistes entourant le batholite gabbro-granitique d'Acari - NE du Brésil: Transfert de chaleur et dynamique des transformations. In: Reunion des Sciences de La Terre, Dynamique et Economie de La Terre. 16th Earth Sciences Meeting, p. 98. Orléans, France.

Spear, F. S., Peacock, S. M. (1990). Metamorphic P-T-path: Program manual and computer exercises for the calculation of metamorphic phase equilibria, pressure-temperature-time paths and thermal evolution of orogenic belts. Washington, D.C.: Geophys, Union, 188 p.

Swanenberg, H. E. C. (1980). Fluid inclusion in high-grade metamorphic rocks from S.W. Norway. Dissertation (Master's Degree). Utrecht: Geologica Ultraiectina, University of Utrecht, 25, 147 p. Available at: http://dspace.library.uu.nl/ handle/1874/217088. Accessed on: Sep 8, 2021.

Van Schmus, W. R., Brito Neves, B. B., Hackspacker, P. C., Babinski, M., Fetter, A., Dantas, E. (1995). Neoproterozoic and late mesoproterozoic sedimentary and volcanic sequences in the Borborema Province, NE Brazil. In: Simpósio de Geologia do Nordeste, 16., 391-393. Recife: SBG.

Van Schmus, W. R., Brito Neves, B. B., Williams, I. S., Hackspacher, P. C., Fetter, A. H., Dantas, E. L., Babinski, M. 
(2003). The Seridó Group of NE Brazil, a late Neoproterozoic pre- to syn- collisional basin in West Gondwana: insights from SHRIMPU-Pb detrital zircon ages and $\mathrm{Sm}-\mathrm{Nd}$ crustal residence (TDM) ages. Precambrian Research, 127(4), 287327. https://orcid.org/0000-0003-2125-3050

Vityk, M. O., Bodnar, R. J. (1995). Do fluid inclusions highgrade metamorphic terranes preserve peak metamorphic density during retrograde decompression? American
Mineralogist, 80, 641-644. Available at: http://minsocam. org/msa/ammin/toc/articles free/1995/vityk p641-644 95. pdf. Accessed on: Sep 8, 2021.

Yardley, B. W. D., Bottrell, S. H. (1992). Silica mobility and fluid movement during metamorphism of the Connemara schists, Ireland. Journal of Metamorphic Geology, 10(3), 453-464. https://doi.org/10.1111/j.1525-1314.1992. tb00096.x 